\title{
Reliability of self-sampling for accurate assessment of respiratory virus viral and immunologic kinetics
}

\author{
Alpana Waghmare ${ }^{1,2,3}$, Elizabeth M. Krantz ${ }^{1}$, Subhasish Baral ${ }^{1}$, Emma Vasquez ${ }^{1}$, Tillie \\ Loeffelholz $^{1}$, E. Lisa Chung ${ }^{1}$, Urvashi Pandey ${ }^{1,4}$, Jane Kuypers ${ }^{5}$, Elizabeth R Duke ${ }^{1,6}$, Keith R. \\ Jerome $^{1,5}$, Alexander L. Greninger ${ }^{5}$, Daniel B. Reeves ${ }^{1}$, Florian Hladik ${ }^{1,4,6}$, E. Fabian Cardozo- \\ Ojeda $^{1}$, Michael Boeckh ${ }^{1,6,7}$, Joshua T. Schiffer ${ }^{1,6,7^{\star}}$
}

${ }^{1}$ Vaccine and Infectious Diseases Division, Fred Hutchinson Cancer Research Center

2 Department of Pediatrics, University of Washington

${ }^{3}$ Center for Clinical and Translational Research, Seattle Children's Research Institute

${ }^{4}$ Department of Obstetrics and Gynecology, University of Washington

${ }^{5}$ Department of Laboratory Medicine, University of Washington

${ }^{6}$ Department of Medicine, University of Washington

${ }^{7}$ Clinical Research Division, Fred Hutchinson Cancer Research Center

${ }^{*}$ Corresponding author:

Joshua T. Schiffer, MD

Fred Hutchinson Cancer Research Center

1100 Fairview Ave N

Seattle, WA 98109

jschiffe@fredhutch.org 
medRxiv preprint doi: https://doi.org/10.1101/2020.04.03.20051706; this version posted April 6, 2020. The copyright holder for this preprint (which was not certified by peer review) is the author/funder, who has granted medRxiv a license to display the preprint in perpetuity. It is made available under a CC-BY-ND 4.0 International license .

\section{Abstract}

2 The SARS-CoV-2 pandemic demonstrates the need for accurate and convenient approaches to

3 diagnose and therapeutically monitor respiratory viral infections. We demonstrated that self-

4 sampling with foam swabs is well-tolerated and provides quantitative viral output concordant

5 with flocked swabs. Using longitudinal home-based self-sampling, we demonstrate nasal

6 cytokine levels correlate and cluster according to immune cell of origin. Periods of stable viral

7 loads are followed by rapid elimination, which could be coupled with cytokine expansion and

8 contraction using mathematical models. Nasal foam swab self-sampling at home provides a

9 precise, mechanistic readout of respiratory virus shedding and local immune responses. 
medRxiv preprint doi: https://doi.org/10.1101/2020.04.03.20051706; this version posted April 6, 2020. The copyright holder for this preprint (which was not certified by peer review) is the author/funder, who has granted medRxiv a license to display the preprint in perpetuity. It is made available under a CC-BY-ND 4.0 International license .

The COVID-19 pandemic is an unprecedented event in modern history. As of March 30, there are 784,000 documented COVID-19 cases, which is surely an underestimation, and 37,638 deaths worldwide with rapidly expanding outbreaks ongoing in dozens of countries ${ }^{1}$. Morbidity and mortality rates are dangerously high in the elderly and those with medical comorbidities ${ }^{2,3}$. Current informal estimates suggest that $20-70 \%$ of humans may become infected without global deployment of a vaccine, which is unlikely to occur in the next year. While social distancing has proven effective in several countries in Asia, these measures might not be sustainable without crippling the global economy and may not be as successfully implemented elsewhere. Under optimistic projections, social distancing may push COVID-19 to a fluctuating pattern during which periodic outbreaks necessitate repeated implementation of social distancing ${ }^{4}$. In all likelihood, this highly contagious and lethal respiratory virus will likely circulate widely for years to come $e^{5}$.

A critical research priority is to develop rapid molecular tests that provide accurate diagnosis, determine infectiousness and transmissibility, and allow for monitoring of viral load during therapy ${ }^{6}$. For numerous viral infections, including influenza, viral load correlates with disease severity and secondary household attack rate ${ }^{7-9}$. Early studies suggest that peak viral load differentiates mild from severe COVID-19 ${ }^{10}$.Furthermore, viral load monitoring during antiviral therapy is a mainstay for various human infections including HIV, hepatitis $B$, cytomegalovirus and hepatitis $\mathrm{C}$ infections ${ }^{11-17}$. Particularly for viruses such as SARS-CoV-2 for which severe clinical outcomes occur in a minority of patients, viral load may serve as a useful surrogate marker to design smaller, but still sufficiently powered treatment studies ${ }^{4,10}$.

Another major unmet medical need is the ability to frequently measure the local mucosal immune response during the course of infection. It is increasingly recognized that tissue resident T-cells and antigen presenting cells are phenotypically and functionally distinct from 
medRxiv preprint doi: https://doi.org/10.1101/2020.04.03.20051706; this version posted April 6, 2020. The copyright holder for this preprint (which was not certified by peer review) is the author/funder, who has granted medRxiv a license to display the preprint in perpetuity. It is made available under a CC-BY-ND 4.0 International license .

circulating immune cells, especially in the setting of respiratory viral infections ${ }^{18-20}$. Therefore, measuring immune cells in blood can fundamentally misclassify the agents responsible for viral elimination at the local level. To assess tissue resident immune cells requires biopsies which are difficult to obtain during active infection. Yet, important shifts in the immune response against respiratory viruses likely occur rapidly and in stages during the early and late phases of viral shedding $^{21}$. Serial measurement of local cytokines may provide a window into the local cellular response ${ }^{22}$, but has yet to be validated from longitudinal clinical samples.

Self-testing for respiratory viruses has been promoted for more than a decade and successfully performed both in research and primary care settings, but regulatory agencies have been slow to accept patient collected samples as valid, especially in the home setting. Recently issued initial guidelines from the United States Food and Drug Administration (FDA) required nasopharyngeal (NP) sampling using flocked swabs for diagnosis of COVID-19 by clinical laboratories ${ }^{23}$. However, as the demand for testing exponentially increases, NP swab availability significantly hampers effective and efficient testing and identification of COVID-19-infected

51 individuals. Currently licensed flocked swabs may not be optimal for patients with vulnerable

52 mucosal membranes and low platelet counts (e.g. following cytotoxic chemotherapy) because

53 they are associated with some discomfort and possible bleeding. Moreover, their general level

54 of discomfort may deter participants from collecting longitudinal samples. This may limit

55 widespread use for self-testing, especially as surveillance testing or for use in vulnerable

56 patients or children. Importantly, a reliable and comfortable home-based self-testing

57 methodology is needed to prevent potentially infected individuals from entering healthcare

58 facilities to be tested and transmitting virus to healthcare workers and other patients. Initial data

59 on foam swabs are promising, suggesting a broader role for home-based self-swabbing for

60 respiratory viral pandemics ${ }^{24,25}$. 
medRxiv preprint doi: https://doi.org/10.1101/2020.04.03.20051706; this version posted April 6, 2020. The copyright holder for this preprint (which was not certified by peer review) is the author/funder, who has granted medRxiv a license to display the preprint in perpetuity. It is made available under a CC-BY-ND 4.0 International license .

62 Here we report data on a novel respiratory virus detection method using self-collected nasal

63 foam swabs. This methodology expands our testing armamentarium with easily collected and

64 comfortable swabs that can be applied to viral load and cytokine kinetic studies. Most

65 importantly, they can be easily scaled and used at home in this time of severe testing shortages

66 and dangerous transmission risk.

67

68 Results.

69

Concordance between foam and flocked nasal swabs for viral detection. Fifteen

71 participants were enrolled within 3 days of respiratory symptom onset (Supp Table 1). Four

72 participants were negative for any respiratory virus from all swabs on our multiplex PCR panel

73 (Table 1). Participants swabbed each nostril with a foam swab and a flocked swab, randomized

74 by order of swab type. Combining results from both nostrils, foam and flocked swabs were

75 concordant for viral detection in $22 / 30$ samples (73.3\%). Among the 12 samples positive by

76 flocked swab, 3 were negative by foam swab. Among 14 samples positive by foam swab, 5

77 were negative by flocked swab (Supp Table 2). Discrepant results occurred exclusively in

78 samples with low viral load (<4 $\log _{10}$ viral copies $\left./ \mathrm{mL}\right)$ (Table 1).

Performance characteristics of foam versus flocked swabs for measurement of nasal

81 viral load. We first compared the yield of samples collected using foam versus flocked swabs

82 within the same nostril. All study participants provided paired specimens from both nostrils to

83 allow for direct comparison. The agreement between samples collected by foam and flocked

84 swabs was generally high, particularly with high viral load samples, with no evidence of higher

85 yield with one method versus the other (Fig 1a). 
medRxiv preprint doi: https://doi.org/10.1101/2020.04.03.20051706; this version posted April 6, 2020. The copyright holder for this preprint (which was not certified by peer review) is the author/funder, who has granted medRxiv a license to display the preprint in perpetuity. It is made available under a CC-BY-ND 4.0 International license .

Focality of respiratory virus shedding in nasal passages. In the same dataset, we compared swab samples obtained with the same swab type from separate nostrils with a total of 15 paired samples. The values for these viral loads were notably higher in one nostril than the other and were less in agreement (Fig 1b). Moreover, the value from the highest nostril strongly agreed with the sum of the two nostrils suggesting that a majority of sampled virus comes from one side (Fig 1c) and that sampling the other side underestimates viral load. Therefore, bilateral sampling is likely required for optimal yield and accurate quantitation.

\section{Comfort and ease of self-collected foam swabs compared to flocked swabs. There was a} trend suggesting that participants found foam swabs more comfortable ( $9 / 15$ participants agreed or strongly agreed that the foam swabs were comfortable to use, whereas $4 / 15$ participants agreed or strongly agreed that flocked swabs were comfortable) although this did not reach statistical significance $(p=0.13)$. Foam swabs were also reported to be easy to collect $(14 / 15$ participants agreed or strongly agreed for foam swabs vs $11 / 15$ for flocked swabs; $p=0.25$ ). Almost all participants (14/15) would consider participating in future research using foam swabs, but only $10 / 15$ if flocked swabs are used $(p=0.13)$.

\section{Ease, comfort and high compliance associated with longitudinal nasal sampling during} an upper respiratory virus infection. We next enrolled a cohort of 9 otherwise healthy, adult study participants who self-sampled their nasal passage serially for 14 days, starting within 3 days of upper respiratory symptoms. One participant contributed serial samples twice. Overall compliance was high: median number of sample days was 14 (range 11-19 days). After completion of the sample collection period, $70 \%$ of participants agreed or strongly agreed that the foam swab was comfortable, $90 \%$ agreed or strongly agreed that the foam swab was easy, and $80 \%$ agreed or strongly agreed that they would participate in future research with foam swabs. Additionally, $80 \%$ of participants agreed or strongly agreed that the swab collection 
medRxiv preprint doi: https://doi.org/10.1101/2020.04.03.20051706; this version posted April 6, 2020. The copyright holder for this preprint (which was not certified by peer review) is the author/funder, who has granted medRxiv a license to display the preprint in perpetuity. It is made available under a CC-BY-ND 4.0 International license .

113 instructions were easy to follow, and $90 \%$ agreed or strongly agreed that the collection kit return

114 process was easy. Serial home-based testing appears to be a well-accepted methodology.

Steady-state nasal passage viral load kinetics during respiratory virus infections. In the

117 longitudinal sampling portion of our study, we were able to detect 14 viruses including seven

118 human rhinovirus (HRV), two coronavirus (CoV), one bocavirus (BoV), two adenovirus (ADV),

119 one human metapneumovirus (MPV) and one respiratory syncytial virus (RSV) cases. There

120 were four instances of viral co-infection, though in each case a dominant virus was evident

121 based on greater duration of shedding and higher viral load (Fig 2a).

Duration of shedding was heterogeneous. In 5 cases, HRV shedding lasted more than a week with one instance of 5-day shedding and one short single-day blip. RSV and MPV episodes were both prolonged. ADV, BoV and CoV shedding was short-lived, though in one case lowlevel ADV shedding was evident throughout the sampling period (Fig 2a). stable from sample to sample (Fig 2a). For HRV, a generalized pattern of viral load steady state or slight gradual decline, followed by rapid elimination was noted. The single case of RSV had a

131 similar profile but with an initial high viral load peak and shorter duration of shedding. The single 132 case of MPV had a more protracted decline with a single re-expansion phase. These transiently 133 observed periods of steady state viral loads are highly unlikely to occur by chance if true viral

134 loads fluctuated or exhibited stochastic noise. Thus, the sampling method appears highly

135 reliable. These data also suggest a brief period of equilibrium between the virus and local 136 immune system before viral elimination. 
medRxiv preprint doi: https://doi.org/10.1101/2020.04.03.20051706; this version posted April 6, 2020. The copyright holder for this preprint (which was not certified by peer review) is the author/funder, who has granted medRxiv a license to display the preprint in perpetuity. It is made available under a CC-BY-ND 4.0 International license .

Viral load kinetics as a predictor of respiratory virus symptoms. In general, the level of symptoms appeared to track with detectable virus, particularly for COV, HRV and MPV. For the single case of RSV, a high number of symptoms persisted beyond viral elimination (Fig 2a). For

141 all HRV infections of greater than one day, duration of shedding correlated strongly with

142 duration of symptoms ( $r=0.87)$. In these HRV infected individuals, symptoms subsided

143 immediately before, concurrent with or soon after viral elimination. Low viral load infections

144 lasting only a day were associated with a smaller number of symptoms than more prolonged

145 higher viral load episodes (Fig 2a).

Stable and surging nasal cytokine levels during respiratory virus infection. We next

148 followed the levels of 20 different cytokines during infection measured from the same specimens

149 from which the viral load was measured. For several cytokines particularly those in the Th2,

150 Th17 and non-defined pathways (IL-2, IL-4, IL-5, IL-10, IL-13, IL-17A and eotaxin), there was

151 notable stability within and between study participants, independent of viral shedding (Fig 2b,

152 Supp Fig 2b). Interferon $\alpha 2 a$ also was relatively invariant across and within persons. This result 153 demonstrates consistency in swabbing technique and yield for molecules that are not impacted 154 by the presence of viral infection, and again validates the precision of our approach.

Other molecules, particularly those associated with cytotoxic T cell responses (granzyme B,

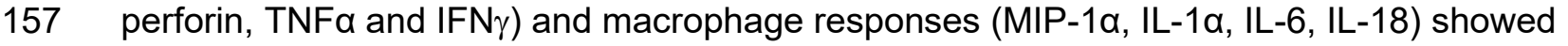

158 monotonic expansion or clearance in response to most infections, with particularly dynamic

159 shifts during the examples of RSV, HPMV and one instance of HRV (p21) with the highest initial

160 viral load (Fig 2b, Supp Fig 2b). Other cytokines such as II-12p70, IL-21, IL-5 and IL-18 were

161 dynamic in participants had monotonic expansion and clearance in response to some but not all 162 infections. 
medRxiv preprint doi: https://doi.org/10.1101/2020.04.03.20051706; this version posted April 6, 2020. The copyright holder for this preprint (which was not certified by peer review) is the author/funder, who has granted medRxiv a license to display the preprint in perpetuity. It is made available under a CC-BY-ND 4.0 International license .

Cytokines correlations according to cellular origin. We next examined the six participants with HRV infection for any correlated cytokine patterns to infer cellular origin. Examples of high positive correlations were noted among analytes associated with a cytotoxic $\mathrm{T}$ cell response (granzyme B, perforin, TNFa, and IL-6), among several macrophage or epithelial cell derived

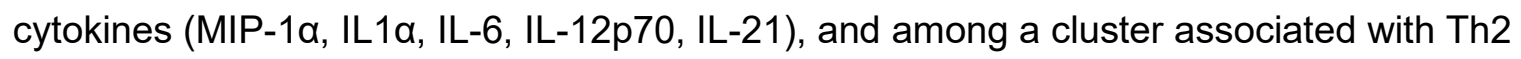
responses (IL-5, IL-10, IL-17). The Th2 associated cytokines (IL-5, IL-10, IL-17) also correlated with many of the cytolytic T cell and macrophage associated cytokines (Fig 3a). HRV viral load was only moderately correlated with a number of parameters, particularly granzyme B, perforin, and IP10 which is a protein induced by IFN $\gamma$. This result suggests that HRV may not induce an intense local molecular immune response in a dose-dependent fashion. Very similar results occurred with inclusion of all samples from all participants in the cohort (Supp Fig 3a).

We next examined cytokine correlations in the 2 persons infected with more inflammatory respiratory viruses: RSV and MPV. We noted similar correlative trends in this data as with HRV. Correlations among related pairs such as granzyme B / perforin, IL-12p70 / IL-21, IL-1 / MIP1alpha, IL-5 / IL-18, TNF-alpha / IL-6, IL-10 / IL-17a and IL-2 / IL-4 were higher for RSV / MPV

180 than for HRV (Fig 3b). For these cytokine pairs, temporal kinetics were often strikingly similar

181 suggesting an equivalent cellular source (Fig $\mathbf{2 b}$, Supp Fig $\mathbf{2 b}$ ). There was also an overall lack

182 of correlation between cytokines associated T cells responses and those associated with

183 epithelial cells and macrophages. Viral load correlated with many cytokines of T cell origin (Fig

184 3b), suggesting that RSV and MPV may induce inflammation is a dose-dependent fashion.

Sample clustering according to degree of inflammation. We next sorted all HRV samples using linkage clustering analysis. This approach demonstrated three classes of samples that were distinguished by the levels of many of the T-cell and macrophage-associated molecular immune factors (Fig $\mathbf{3 b}$ ). The minority of samples (blue class) with the highest levels of 
medRxiv preprint doi: https://doi.org/10.1101/2020.04.03.20051706; this version posted April 6, 2020. The copyright holder for this preprint (which was not certified by peer review) is the author/funder, who has granted medRxiv a license to display the preprint in perpetuity. It is made available under a CC-BY-ND 4.0 International license .

granzyme B, perforin, IL-6, IL-1 1 , MIP-1 $\alpha$ and IFN $\gamma$ all had high viral loads. These samples were

191 from two participants. All six participants had some samples in the least inflammatory class

192 (grey) and 5 participants had samples in the moderate inflammatory class (green). These data

193 indicate that the inflammatory immune milieu in the HRV-infected nasal passage is dynamic

194 over time, but tilts toward higher inflammation with higher viral loads. Very similar results were

195 observed when all samples were analyzed though only two classes of samples were

196 distinguished (Supp Fig 3b).

We next sorted the RSV and MPV samples using linkage clustering and could not identify the optimal number of clusters. We selected two clusters which were differentiated according to

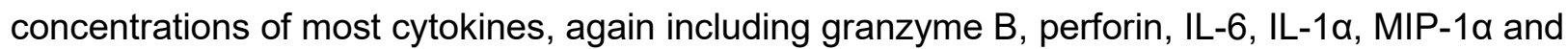
IFN $\gamma$. In the case of these viruses, the more inflammatory cytokine cluster clearly associated with high viral loads for both RSV and MPV (Fig 3d).

Mathematical modeling. We performed mathematical modeling separately on data from the participant infected with RSV to examine whether complex immune and viral data from our samples could be coupled mechanistically. We first developed the ordinary differential equation model in equation (1) to link RSV viral load and early and late immune responses and evaluated which cytokines may track those responses. For the early immune response, we found that only the $\log _{10}$ of the concentration change of IFN- $\gamma$ and IP-10 was positively correlated to the viral

210 load during the first 5 days after enrollment (Supp Fig 4a-b), so we evaluated models for only

211 these two cytokines to track the RSV-early immune response. For the late immune responses,

212 we evaluated the model for fit to all observed cytokines (Supp Fig 4c). An equivalent approach 213 was carried forward to model MPV. 
medRxiv preprint doi: https://doi.org/10.1101/2020.04.03.20051706; this version posted April 6, 2020. The copyright holder for this preprint (which was not certified by peer review) is the author/funder, who has granted medRxiv a license to display the preprint in perpetuity. It is made available under a CC-BY-ND 4.0 International license.

215 In Fig 4a, we show our resulting model schematic. Differential equations capture the rate of

216 change of susceptible cells, infected cells, viral load (Fig 4b) and two cytokines (Fig 4c-d). The

217 best fit was achieved with a model assuming IFNy concentration dependent killing during the

218 first early stages of infection, and IL-21 mediated elimination of infected cells with a mechanism

219 saturating the amount of possible killing above a certain level of IL-21.

221 The model suggests that for RSV, an early surge in IFNy leads to a slight rise in per cell killing

222 rate of infected cells (Fig 4e) leading to a mass elimination of infected cells at a rate of 10

223 million cells per day and a decrease in viral load by a factor of 100-1000. However, this

224 response does not clear the virus. A steady state viral load persists for 4 days until an IL-21

225 mediated response appears. This response kills far more rapidly, but not as intensely as the

226 IFNy response. Together, these responses remove the remaining infected cells by day 7 after

227 onset of symptoms (Fig 4f). Model fitting using data in which IP10 provides early clearance

228 rather than IFNy results in worse fit to the data (Supp Fig 4c, 4d). For late results, IL-21

229 allowed the best fit and other cytokines was less successful. This suggests that these two

230 molecules may play a major role in RSV control in vivo but does not rule out the effects of other

231 cytokines and effector molecules in limiting infection.

233 We next fit the same model to the data from participant infected with MPV and found that the

234 model is able to recapitulate viral load, IFNy and IL-21, projects similar killing patterns during the 235 early and late immune responses to the RSV model (Supp Fig 5).

237 Discussion

239 Here we demonstrate that home self-sampling with nasal foam swabs is well-tolerated and 240 provides reliable results for monitoring viral load as well as the molecular immune response to 
medRxiv preprint doi: https://doi.org/10.1101/2020.04.03.20051706; this version posted April 6, 2020. The copyright holder for this preprint (which was not certified by peer review) is the author/funder, who has granted medRxiv a license to display the preprint in perpetuity. It is made available under a CC-BY-ND 4.0 International license .

241 respiratory virus infection. These results have enormous practical implications. Self-collection at

242 home is safe, non-invasive and easily learned, allowing a reliable method for diagnosis as well

243 as therapeutic monitoring. Because our kits could easily be used at home or in a drive through

244 testing environment, they provide an avenue to eliminate contact between an infected and

245 contagious person, and health care providers. They could also be used in the hospital or clinic

246 setting, thereby saving personnel time and personal protective equipment. The use of

247 comfortable, safe and affordable foam swabs also highlights the possibility of scaling this

248 approach to pediatric, adult, elderly and immunocompromised populations. For the current

249 SARS-CoV-2 pandemic, and future deadly respiratory virus epidemics, home self-swabbing will

250 be a vital tool.

252 The simplicity of the sampling approach also facilitates large scale research studies of viral 253 pathogenesis and transmission dynamics in which participants self-sample for months. Our

254 inability to stop the spread of the COVID-19 epidemic in the United States has demonstrated a 255 poor overall understanding of cryptic transmission patterns of respiratory viruses. Because our 256 approach is safe, well accepted, and easy to implement, longitudinal sampling studies within 257 families, workplaces and at large conferences are highly feasible.

259 We have previously demonstrated increased sensitivity of self-collected foam nasal swabs 260 compared to nasal washes in immunocompetent adults with respiratory viral infections ${ }^{24}$.

261 Additional anatomical sites have also been considered for increasing yield, and current FDA

262 recommendations suggest use of both a mid-turbinate nasal swab and an oropharyngeal swab

263 to maximize yield in the absence of nasopharyngeal swabbing ${ }^{23}$. Our prior data demonstrate

264 that self-collected throat swabs in addition to self-collected foam nasal swabs do not increase 265 yield significantly for respiratory viruses ${ }^{26}$, suggesting that additional oral swabbing may not be 266 needed, especially in the setting of swab shortages. Self-collected foam swabs have been used 
medRxiv preprint doi: https://doi.org/10.1101/2020.04.03.20051706; this version posted April 6, 2020. The copyright holder for this preprint (which was not certified by peer review) is the author/funder, who has granted medRxiv a license to display the preprint in perpetuity. It is made available under a CC-BY-ND 4.0 International license .

267 for longitudinal studies in solid organ transplant recipients ${ }^{25}$, with good compliance and

268 participants reporting no issues with swab discomfort. The specific swab used in these prior

269 studies and our present study were custom designed to limit discomfort while maintaining

270 adequate sensitivity; we have demonstrated stability with these swabs with and without

271 transport media after storage at room temperature for 7 days ${ }^{24}$, making them ideal for home

272 self-testing followed by shipment directly to a testing lab. Furthermore, SARS-CoV-2 has been

273 shown to be highly stable on surfaces ${ }^{27}$, making home foam swabbing a feasible and attractive

274 option for this pathogen.

275

276 We also demonstrate an ability to accurately sample local cytokines which are present at

277 picogram levels, again using the same foam swabs from which viral measurements were made.

278 The combination of precise virologic and immunologic readouts of local infection is highly

279 relevant for developing clinical severity scores and biomarkers. While studies are beginning to

280 show that viral load may be predictive of COVID-19 severity ${ }^{10}$, it is equally plausible that the

281 intensity and phenotype of the early local cellular immune response plays a causal role in

282 limiting the extent of infection ${ }^{28}$. By following the molecular immune response closely with daily

283 sampling intervals, we also provide adequate data for mathematical models that can link

284 specific arms of the cellular immune response to pathogen control in real time ${ }^{22}$, a goal that has

285 been difficult to attain for a majority of viral infections in humans.

287 Our study demonstrates several novel features of respiratory virus kinetics. RSV infection

288 achieves a brief, extremely high, viral load, followed by a steady state and a final rapid phase of

289 elimination. HRV also has a remarkably stable viral load in most participants before being

290 rapidly eliminated. During a majority of our observed episodes, viral shedding is strongly

291 correlated with symptoms. As viral load decreases, symptoms tend to dissipate. 
medRxiv preprint doi: https://doi.org/10.1101/2020.04.03.20051706; this version posted April 6, 2020. The copyright holder for this preprint (which was not certified by peer review) is the author/funder, who has granted medRxiv a license to display the preprint in perpetuity. It is made available under a CC-BY-ND 4.0 International license .

293 Certain molecular immune responses are constitutively expressed, and vary little between and

294 within participants, particularly those associated with Th2 mechanisms that are unlikely to play a

295 role in elimination of virally infected cells. On the other hand, small molecules associated

296 specifically with tissue-resident T cell responses such as granzyme B, perforin and IFNy, and

297 macrophages such as IL-6 and IL-1 expand and contract during the course of viral shedding,

298 particularly with more severe infections such as RSV and HPMV. Our technique therefore

299 overcomes a fundamental limitation of human immunological studies, which is the inability to

300 sample over temporally granular time intervals at the mucosal site of viral replication.

302 Further validation of our technique is demonstrated with mathematical modeling that links 303 expression of certain cytokines with early and late elimination of virus. For RSV and MPV, we 304 demonstrate that an early surge in IFNy is coupled with elimination of a massive number of 305 infected cells but is insufficient for complete containment of infection, which is achieved several 306 days later concurrent with slower expansion IL-21. Notably, IL-21 has previously been identified 307 as required for RSV elimination in murine models ${ }^{29-31}$ In our model, it induces an extremely high 308 death rate of infected cells once above a certain concentration. Larger scale studies may be 309 able to link surges in different cytokines with different respiratory viruses, including SARS CoV-

3102 , and to differentiate severity using these techniques. Of particular interest is combining

311 information on levels of local cytokine levels with viral load at presentation, along with patient 312 metadata, to predict infection severity.

314 There are important limitations to our study. Correlations between foam and flocked swabs were 315 weaker at low viral loads. However, stochastic variation in low viral load samples is inherent to 316 quantitation of viruses which replicate in mucosa. Additional variables such as storage

317 temperature may have contributed to viral quantification variability. Our samples size for

318 longitudinal episodes is relatively low, particularly when considered on a per virus basis. A 
medRxiv preprint doi: https://doi.org/10.1101/2020.04.03.20051706; this version posted April 6, 2020. The copyright holder for this preprint (which was not certified by peer review) is the author/funder, who has granted medRxiv a license to display the preprint in perpetuity.

It is made available under a CC-BY-ND 4.0 International license .

319 greater number of participants will be required to definitively differentiate kinetics patterns of

320 different respiratory viruses, as well as the cytokine profiles associated with their containment.

321 Selection of cytokines as incomplete and may have missed critical responders to viral infection.

322 Our mathematical models dramatically oversimplify the coordinated immune response against

323 the virus but do generate testable hypotheses that IFNY and IL-21 are viral for early and late

324 containment of infection.

325

326 In summary, we establish a foam swab-based sampling method that is optimal for patient self-

327 testing, both at home and in the clinical setting, permits serial therapeutic monitoring, and is

328 suitable for tracking the natural virologic and immunologic course of respiratory virus infections.

329 We recommend that this method be adapted to future clinical and research applications,

330 including for the study of SARS-CoV-2. 
medRxiv preprint doi: https://doi.org/10.1101/2020.04.03.20051706; this version posted April 6, 2020. The copyright holder for this preprint (which was not certified by peer review) is the author/funder, who has granted medRxiv a license to display the preprint in perpetuity. It is made available under a CC-BY-ND 4.0 International license .

\section{Methods.}

334 Protocol.

335 The study was approved by the Institutional Review Board at Fred Hutchinson Cancer Research 336 Center.

Flocked vs foam swab study: Participants with symptoms of an acute respiratory illness, defined

339 as the presence of respiratory symptoms (Supp Table 1) for less than 3 days, were enrolled in

340 the study. Each participant completed 2 sample collections, each separated by one hour. At

341 each time point, the participant collected either a) two self-collected Copan flocked swabs (\#23-

342 600-966), one from each nostril or b) two self-collected Puritan foam swabs (Puritan Medical

343 Red \#25-1805-SC 2), one from each nostril. The foam swab was designed in a mushroom

344 shape to maximize swabbing from the nostril wall (Supp Fig 1) and has been used in previous

345 studies in HCT and lung transplant recipients ${ }^{24,25}$. Foam and flocked swabs were self-collected

346 following instruction by trained study personnel. Participants used a saline spray bottle with a

347 nozzle to dispense 5 sprays into one nostril. The participant then placed the swab into the

348 moistened nostril and rotated the swabs and blew for about 5 seconds or 5 rotations. Following

349 sample collection, participants were asked to complete a brief survey to assess the tolerability

350 and acceptability of the various testing methods.

352 Immediately following collection, each nasal swab was placed in a conical vial containing 1000ul

353 of cytokine preservative buffer consisting of phosphate buffered saline (PBS) with 10\% Igepal,

$3541 \%$ protease inhibitor cocktail (EMD Millipore: $539131-1 \mathrm{VL}$ ), and $0.25 \%$ bovine serum albumin

355 (BSA; Sigma A7906-100G). All swabs from the right nostril were stored at $-20^{\circ} \mathrm{C}$; all swabs from

356 the left nostril were stored at $4^{\circ} \mathrm{C}$. All samples were stored for 1 week prior to processing. Swab

357 collection order (flocked vs foam) was randomized using an online randomization tool 
medRxiv preprint doi: https://doi.org/10.1101/2020.04.03.20051706; this version posted April 6, 2020. The copyright holder for this preprint (which was not certified by peer review) is the author/funder, who has granted medRxiv a license to display the preprint in perpetuity. It is made available under a CC-BY-ND 4.0 International license .

358 (www.randomizer.org). To compare the number of participants who agreed or strongly agreed with statements regarding comfort, ease of use, and participation in future research for foam versus flocked swabs, we used McNemar's test with exact p-values.

Longitudinal sampling study: Participants with symptoms of an acute respiratory illness, defined

363 as presence of respiratory symptoms (Supp Table 1) for less than 3 days, were enrolled in the

364 study. Each participant collected two Puritan foam nasal swabs, one from each nostril, per day

365 for 14 days after enrollment or until symptoms resolved, whichever was longer. Participants

366 completed a daily electronic symptom survey, in which participants were asked to record the

367 presence and severity of symptoms in specific categories: nasal, eyes, ears, throat, chest,

368 gastrointestinal, general, sleep and sensory changes (Supp Table 1). Following completion of

369 the 14-day sample collection, participants were asked to complete a brief survey to assess the

370 tolerability and acceptability of the testing methods.

372 Immediately following collection, each nasal swab was placed in a conical vial containing 1000ul

373 of cytokine preservative buffer consisting of $0.1 \%$ Tween $20,1 \%$ protease inhibitor (EMD

374 Millipore: 539131-1VL), 1\% BSA (Sigma A7906-100G), 1X ProClin300 (at 1:2000, diluted with

375 PBS). Participants were instructed to store collected swabs in the participant's home

376 refrigerator. Participants then transported collected samples to the lab in insulated bags

377 containing ice packs within one week of sample collection. Nasal swabs were processed within

378 one week of sample collection. Collections from each nostril were combined for the final

379 analyses.

$381 \quad$ Lab methods.

382 Sample processing: Each conical vial containing a swab was vortexed and 500ul of buffer was 383 removed and stored at $-80^{\circ} \mathrm{C}$ for $\mathrm{PCR}$ analysis. The swab was then removed from the conical 
medRxiv preprint doi: https://doi.org/10.1101/2020.04.03.20051706; this version posted April 6, 2020. The copyright holder for this preprint (which was not certified by peer review) is the author/funder, who has granted medRxiv a license to display the preprint in perpetuity. It is made available under a CC-BY-ND 4.0 International license .

384 vial and placed in a pre-chilled 0.45um SPIN-X filter and the handle of the swab was removed.

385 The buffer remaining in the conical vial was then transferred to the SPIN-X filter containing the 386 swab. The SPIN-X filter was then spun at $13000 x g$ for 15 minutes at $4^{\circ} \mathrm{C}$ with no brake. 300 ul of 387 fresh cytokine preservative buffer was then added to the SPIN-X filter which was then incubated 388 on wet ice for 5 minutes then spun again at $13000 x g$ for 30 minutes at $4^{\circ} \mathrm{C}$ with no brake. The 389 swab and filter were discarded, and the filtered buffer was then aliquoted in 100ul increments 390 and stored at $-80^{\circ} \mathrm{C}$ until further testing.

Viral testing: Nasal swab specimens were tested using a multiplex PCR testing for 11

393 respiratory viruses [adenovirus $A-F$, human rhinovirus (HRV), influenza $A$ and $B$, parainfluenza

394 viruses (PIV) 1-4, human coronavirus (CoV), bocavirus (BoV), respiratory syncytial virus (RSV)

395 and human metapneumovirus (MPV)] as previously described ${ }^{32}$.

397 Cytokine testing: Cytokine levels were quantified in nasal specimens using the

398 electrochemiluminescence-based Mesoscale Discovery (MSD) platform. For the longitudinal 399 sampling study, the following panels were used: U-PLEX Biomarker Group 1 (Eotaxin, IFN- $\alpha 2 a$, 400 IL-1, IL-8, IL-12p70, IL-13, IL-18, IL-21, IP-10, MIP-1 $\alpha$ ), U-PLEX Custom Biomarker (IFN-y, IL-2, 401 IL-4, IL-5, IL-6, IL-10, IL-17A, TNF- $\alpha$ ), R-PLEX Granzyme B, and R-PLEX Perforin. Preparation 402 of analyte detection plates was done following the manufacturer's instructions (Meso Scale 403 Diagnostics). A series of 8 concentrations of biomarkers standards and the test samples were 404 added in duplicates to the wells. The plates were incubated shaking for 1 hour. In parallel to 405 plate incubation, the plate-respective SULFO-TAG labeled detection antibodies were combined. 406 The plates were washed, and the respective detection antibody mixture was added to each well. 407 The plates were incubated shaking for 1 hour. Plates were washed, then $2 X$ Read buffer was 408 added to each well. The plates were read on the MSD Plate reader (MESO QuickPlex SQ 120). 409 Protein concentrations were determined using the MSD Discovery Workbench 4.0 analysis 
medRxiv preprint doi: https://doi.org/10.1101/2020.04.03.20051706; this version posted April 6, 2020. The copyright holder for this preprint (which was not certified by peer review) is the author/funder, who has granted medRxiv a license to display the preprint in perpetuity. It is made available under a CC-BY-ND 4.0 International license .

software. The light intensities from samples were interpolated using a four-parameter logistic fit

411 to a standard curve of electrochemiluminescence generated from the known concentrations of

412 the standards. The lower limit of detection for each marker can be found on the manufacturer's

413 website: https://www.mesoscale.com/ /media/files/handouts/assaylist.pdf.

415 Statistical analysis. For the foam versus flocked swab study, PCR results that were positive on

416 the qualitative assay but below the limit of detection were imputed as 500 copies per ml, using

417 the limit of detection divided by two. PCR results were log10-transformed and negative results

418 were assigned a value of 0 . The concordance correlation coefficient (CCC) was used to

419 measure agreement of quantitative results between paired samples (foam versus flocked

420 swabs, left versus right nostril samples, sum versus maximum value from left and right

421 nostrils) $)^{33}$. For the longitudinal sampling study, cytokine results that were below the fitted curve

422 range were assigned the value of the lower limit of detection divided by two and results that

423 were above the fitted curve range were assigned the value of the upper limit of detection.

424 Results were log10-transformed for analysis. Symptoms are represented as the total number of

425 symptoms present for each day, out of a total of 26 (Supp Table 1). SAS, version 9.4 (SAS

426 Institute, Cary, North Carolina) and Stata, version 16.1 (StataCorp, College Station, Texas)

427 were used for analysis.

429 Cytokine clustering. To check whether the samples could be classified into groups with similar 430 cytokine concentrations, we performed a cluster analysis of the samples where each sample is 431 an array of the 20 measured cytokine concentrations. First, we checked for cluster tendency of 432 the samples using Hopkin statistic $(H)^{34,35}$. H can have values between 0 and 1, where values 433 close to 1 indicate that the samples are highly clustered and values close to 0.5 indicate random 434 samples. When calculated $\mathrm{H}$ (get_clust_tendency function in R3) was greater than 0.5 , we did a 435 linkage hierarchical clustering with Euclidean distances of the samples ${ }^{36}$. 
medRxiv preprint doi: https://doi.org/10.1101/2020.04.03.20051706; this version posted April 6, 2020. The copyright holder for this preprint (which was not certified by peer review) is the author/funder, who has granted medRxiv a license to display the preprint in perpetuity. It is made available under a CC-BY-ND 4.0 International license .

\section{Mathematical modeling.}

438 Model assumptions: To understand how the immune system drives respiratory virus dynamics

439 we used an acute viral infection model that distinguishes between early and late responses to

440 RSV. In this model, susceptible cells $(S)$ are infected at rate $\beta V S$ by free RSV virus (V). The

441 impact of host immunity is tracked by modeling two cytokines that are plausible surrogates for

442 those responses. We assumed RSV-infected cells (I) are cleared by: (1) an innate response

443 with rate $\kappa_{G} G$ mediated by an innate immune response tracked by an initial cytokine (G); and (2)

444 an acquired response with rate $\frac{\kappa_{C} C^{r}}{C^{r}+\phi^{r}}$ mediated by an acquired immune response tracked by a

445 second cytokine $(C)$. The Hill coefficient $r$ parameterizes the nonlinearity of the response and

446 allows for rapid saturation of the killing. In the model, $G$ is secreted proportionally to the number

447 of infected cells with rate $\omega_{G} I$ and cleared with rate $\delta_{G} G$. $C$ is secreted in a non-linear fashion

448 with density dependent rate $\omega_{C} \frac{I}{I+I_{50}} C$ and cleared with rate $\delta_{C} C$. Finally, free virus is produced

449 at a rate $\pi$ and cleared with rate $\gamma$. The model is expressed as a schematic (Fig 4a) and here as

450 a system of ordinary differential equations:

$$
\begin{aligned}
& \frac{d S}{d t}=-\beta V S \\
& \frac{d I}{d t}=\beta V S-\kappa_{G} G I-\kappa_{C} \frac{C^{r}}{C^{r}+\phi^{r}} I \\
& \frac{d V}{d t}=\pi I-\gamma V \\
& \frac{d G}{d t}=\omega_{G} I-\delta_{G} G \\
& \frac{d C}{d t}=\omega_{C} \frac{I}{I+I_{50}} C-\delta_{C} C
\end{aligned} .
$$

452 Selection of surrogate cytokines: To select the initial cytokine to model the surrogate for early

453 immune response $(G)$ we performed Pearson's correlation tests between the RSV viral load

454 from day 1 until day 5 post-enrollment and the $\log _{10}$ of the concentration change of each

455 cytokine until day 5 post-enrollment. We modeled equation (1) only for the cytokines with

456 positive correlation that were statistically significant. Then for each cytokine obtained for 
457 variable $G$ we tried model fitting to all cytokines for variable $C$ individually. We selected the

458 surrogate for the acquire immune response to RSV $(C)$ the cytokine that gave a lower sum of

459 squares error in the model fitting.

461 Model fitting: Model fitting: We performed fitting of model in equation (1) to the data assuming $462 t=0$ as the time of enrollment. We also assumed initial concentrations of $S(0)=10^{7}$ cells $/ \mu \mathrm{L}$,

$463 I(0)=\frac{\pi V(0)}{\gamma}$ and obtained $V(0), G(0)$ and $C(0)$ from the viral load and cytokine initial

464 concentrations, respectively. We estimated the remaining best parameters using nonlinear

465 least-squares. Implementation used the differential evolution (DEoptim) and the L-BFGS-B

466 (optim) algorithms in R.

468 Model predictions: We used equation (1) and best estimates from the best model fits to

469 calculate the absolute number of infected cells killed and the killing rate per cell during early and

470 late immune responses against RSV. The number of eliminated infected cells at any time was

471 calculated by the equations $\kappa_{G} G I$ and $\kappa_{C} \frac{C^{r}}{C^{r}+\phi^{r}} I$ for the early and late responses, respectively.

472 Similarly, we computed the killing rate per cell during early and late response as $\kappa_{G} G$ and

$473 \kappa_{C} \frac{C^{r}}{C^{r}+\phi^{r}}$. 
medRxiv preprint doi: https://doi.org/10.1101/2020.04.03.20051706; this version posted April 6, 2020. The copyright holder for this preprint (which was not certified by peer review) is the author/funder, who has granted medRxiv a license to display the preprint in perpetuity. It is made available under a CC-BY-ND 4.0 International license .

\section{Acknowledgements}

475 We would like to thank our study participants.

476

\section{Author Contributions}

478 AW designed the experiments and wrote the manuscript. EMK performed statistical analysis, 479 SB performed statistical analysis and mathematical modeling. EV performed data analysis. TL 480 enrolled participants and performed experiments. ELC enrolled participants and performed 481 experiments. UP performed the cytokine analysis. JK performed respiratory virus PCR. ERD 482 wrote the manuscript. KRJ designed the respiratory virus PCR. ALG performed the respiratory 483 virus PCR. DBR performed mathematical modeling. EFCO performed mathematical modeling. 484 MB designed the experiments and wrote the manuscript. JTS designed the experiments, designed the mathematical modeling and wrote the manuscript.

\section{Funding Statement}

488 This work was supported by the National Institutes of Health [grant numbers K24 HL093294-06

489 (M.B.), K23 Al114844-02 (A.W.)] and the Fred Hutchinson Cancer Center Vaccine and 490 Infectious Diseases Faculty Initiative Fund (M.B. and J.S.).

\section{Competing Interests Statement}

493 A.W.: Kyorin (personal fees), Ansun (research support), VB Tech (research support), all outside

494 of the submitted work. A.G.: Abbott Molecular, personal fees, outside of the submitted work.

495 M.B.: Kyorin (personal fees), Gilead (research support, personal fees), ReViral (personal fees_, 496 Janssen (research support, personal fees), Ansun (research support, personal fees), Moderna 497 (personal fees); Vir Bio (research support, personal fees); GSK (personal fees), Pulmocide 498 (personal fees), VB Tech (research support), Bavarian Nordic (personal fees), DMA (personal 499 fees), Allovir (personal fees), all outside of the submitted work. 
medRxiv preprint doi: https://doi.org/10.1101/2020.04.03.20051706; this version posted April 6, 2020. The copyright holder for this preprint (which was not certified by peer review) is the author/funder, who has granted medRxiv a license to display the preprint in perpetuity. It is made available under a CC-BY-ND 4.0 International license .

Figure legends

Figure 1: Comparison of viral loads between self-collected foam and flocked swabs. (a)

503 Viral loads from the same nostril using flocked and foam swabs are concordant, particularly at

504 higher viral loads. (b) Differential viral loads with the same swab type, observed between

505 nostrils, show moderate concordance. (c) Viral load from the highest nostril strongly agrees with

506 the sum of the two nostrils suggesting that a majority of sampled virus comes from one side.

507 Overlapping data points have been jittered to allow viewing of all data points. CCC $=$

508 concordance correlation coefficient; CoV = coronavirus; FluA = Influenza A; HRV = human

509 rhinovirus; PIV3 = parainfluenza virus 3; RSV = respiratory syncytial virus.

Figure 2: Viral load, symptoms and cytokine levels in serial sampling in both nostrils.

512 Each row represents a participant. (a) Viral load (lines) and quantity of symptoms (bars) are

513 shown on left and often tracked with each other longitudinally. Serial sampling in both nostrils

514 with foam swabs reveals a steady state for HRV, RSV and HMPV viral loads prior to rapid

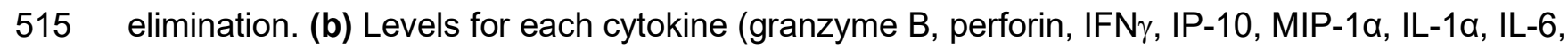

516 TNF- $\alpha$, IL-20p70, IL-21) are shown on the right. Paired cytokines show concordant expansion

517 and clearance phases. HRV = human rhinovirus; RSV = respiratory syncytial virus; MPV =

518 metapneumovirus; $\mathrm{ADV}=$ adenovirus; $\mathrm{CoV}=$ coronavirus, $\mathrm{BoV}=$ bocavirus.

Figure 3: Cytokines correlate according to cellular origin during respiratory virus

522 participants p16, p17, p18, p19, p20, p21 and p22b who have HRV infection. (c, d) Data from

523 participants p22 and p23 who have RSV and MPV respectively. (a, c) Correlation plots with

524 strong correlation according to cell type origin. X indicates a non-significant correlation. Color 525 intensity and the size of the dot are proportional to the Pearson correlation coefficient. For both 
datasets, strong positive correlations are noted within cytokines linked with cytolytic T-cell

527 responses; macrophage responses; and $\mathrm{T}_{\mathrm{H}} 2$ responses. (b, d) Linkage clustering analysis of

528 samples (columns) demonstrates classes of samples based on the concentration of

529 inflammatory cytokines. (b) For HRV infections, a minority of samples (blue class) from 2

530 participants and with the highest levels granzyme B, perforin, IL-6, IL-1 $1 \alpha$, MIP-1 $1 \alpha$ and IFN $\gamma$ all

531 had high viral loads. All six participants had samples in the least inflammatory class (grey) and

532 five participants had samples in the moderate inflammatory class (green). (d) For RSV and

533 MPV, inflammatory (blue) and non-inflammatory (green) sample clusters are evident. The

534 inflammatory class of samples is highly associated with the highest viral loads. VL = viral load;

$535 \quad \mathrm{DL}=$ detection limit.

Figure 4: Mathematical modeling of a single participant's RSV kinetics and the early and

538 late immune responses tracked by IFN- $\gamma$ and IL-21. (a) Schematic representation of the

539 model. S represents cells susceptible to RSV; I, RSV-infected cells; V, RSV virions; G, IFN- $\gamma$

540 concentration and C, IL-21 concentration. Best fit models to (b) viral load, (c) IFN- $\boldsymbol{\gamma}$ and (d) IL-

54121 measurements using a nonlinear least-squares approach. Circles represent the data, and

542 black-solid lines the best model predictions. Models fit better to these cytokines than all others

543 charted in Fig 2 and Sup fig 2. (e) Model estimates of the killing rate per cell of infected cells

544 mediated by IFN- $\boldsymbol{\gamma}$ and IL-21, calculated as $\kappa_{G} G$ and $\kappa_{C} \frac{C^{r}}{C^{r}+\phi^{r}}$, respectively. (f) Total number of

545 infected cell deaths mediated by IFN- $\gamma$ and IL-21, computed as $\kappa_{G} G I$ and $\kappa_{C} \frac{C^{r}}{C^{r}+\phi^{r}} I$,

546 respectively. In (e) and (f) blue and green lines represent model predictions of the effects

547 mediated by IFN- $\gamma$ and IL-21, respectively. 
medRxiv preprint doi: https://doi.org/10.1101/2020.04.03.20051706; this version posted April 6, 2020. The copyright holder for this preprint (which was not certified by peer review) is the author/funder, who has granted medRxiv a license to display the preprint in perpetuity. It is made available under a CC-BY-ND 4.0 International license .

552 Supplemental Figure 2: Symptoms, viral load and cytokine levels in serial sampling in

553 both nostrils in all participants for remainder of cytokines evaluated. Each row represents

554 a participant. (a) Viral load (lines) and quantity of symptoms (bars) are shown on left and often

555 tracked with each other longitudinally. Serial sampling in both nostrils with foam swabs reveals a

556 steady state for HRV, RSV and HMPV viral loads prior to rapid elimination. (b) Levels for each

557 cytokine are shown on the right. Paired cytokines show concordant kinetics. HRV = human

558 rhinovirus; RSV = respiratory syncytial virus; MPV = metapneumovirus; $A D V=$ adenovirus; CoV

$559=$ coronavirus, BoV = bocavirus.

\section{Supplemental Figure 3: Cytokines correlate according to cellular origin during} respiratory virus infection, while samples cluster according to level of inflammation. Data is from all participants. (a) Correlation plot with strong correlation according to cell type origin. $\mathrm{X}$ indicates a non-significant correlation. Color intensity and the size of the dot are proportional to the Pearson correlation coefficient. Strong positive correlations are noted within cytokines linked with cytolytic $T$ cell responses; macrophage responses; and $T_{H} 2$ responses. (b) Linkage clustering analysis of all samples demonstrates classes of samples based on the concentration of inflammatory cytokines. A minority of samples (grey class) had highest levels granzyme B, perforin, IL-6, IL-1 $\alpha$, MIP-1 $\alpha$ and IFN $\gamma$. VL = viral load; $\mathrm{DL}=$ detection limit.

\section{Supplemental Figure 4: Selection of surrogate cytokines for modeling early and late}

572 immune responses against RSV. Scatterplot between RSV viral load from days 1 to 5 post

573 enrollment and the $\log _{10}$ concentration of (a) IFNy and (b) IP-10 until day 5 post enrollment. p-

574 values and correlation coefficient obtained using Pearson's test. Correlation test for all other

575 cytokines was not statistically significant. (c) Sum of squared error (SSE) of the best model fits

576 of equation (1) assuming early response $(G)$ is tracked by IFNy and late response $(C)$ is tracked 
medRxiv preprint doi: https://doi.org/10.1101/2020.04.03.20051706; this version posted April 6, 2020. The copyright holder for this preprint (which was not certified by peer review) is the author/funder, who has granted medRxiv a license to display the preprint in perpetuity. It is made available under a CC-BY-ND 4.0 International license .

577 by each of the cytokines in x-axis. Lowest SSE (best fit) is obtained when late response is

578 tracked by IL-21. (d) Sum of squared error (SSE) of the best model fits of equation (1)

579 assuming early response $(G)$ is tracked by IP10 and late response $(C)$ is tracked by each of the

580 cytokines in X-axis. Lowest SSE (best fit) is obtained when late response is tracked by IL-21.

582 Supplemental Figure 5. Mathematical modeling of a single participant's MPV kinetics and

583 the early and late immune responses tracked by IFN- $\gamma$ and IL-21. (a) Schematic

584 representation of the model. S represents cells susceptible to MPV; I, MPV-infected cells; V,

585 RSV virions; G, IFN- $\gamma$ concentration and C, IL-21 concentration. Best fit models to (b) viral load,

586 (c) IFN- $\gamma$ and (d) IL-21 measurements using a nonlinear least-squares approach. Circles

587 represent the data, and black-solid lines the best model predictions. Models fit better to these

588 cytokines than all others charted in Fig 2 and Sup fig 2. (e) Model estimates of the killing rate

589 per cell of infected cells mediated by IFN- $\boldsymbol{\gamma}$ and IL-21, calculated as $\kappa_{G} G$ and $\kappa_{C} \frac{C^{r}}{C^{r}+\phi^{r}}$,

590 respectively. (f) Total number of infected cell deaths mediated by IFN- $\gamma$ and IL-21, computed as

$591 \kappa_{G} G I$ and $\kappa_{C} \frac{C^{r}}{C^{r}+\phi^{r}} I$, respectively. In (e) and (f) blue and green lines represent model predictions

592 of the effects mediated by IFN- $\gamma$ and IL-21, respectively. 
Table 1: Viral loads in matched foam versus flocked swabs in participants with new onset respiratory symptoms.

\begin{tabular}{|c|c|c|c|c|c|}
\hline $\begin{array}{l}\text { Participant } \\
\text { number }\end{array}$ & Virus & $\begin{array}{l}\text { Foam right } \\
\text { Log10 } \\
\text { copies/ml }\end{array}$ & $\begin{array}{l}\text { Foam left } \\
\text { Log10 } \\
\text { copies } / \mathrm{ml}\end{array}$ & $\begin{array}{l}\text { Flocked right } \\
\text { Log10 } \\
\text { copies } / \mathrm{ml}\end{array}$ & $\begin{array}{l}\text { Flocked left } \\
\text { Log10 } \\
\text { copies } / \mathrm{ml}\end{array}$ \\
\hline p1 & PIV3 & 6.12 & 3.79 & 5.64 & 3.19 \\
\hline p2 & HRV & 7.18 & 8.02 & 6.35 & 7.54 \\
\hline p3 & neg & 0 & 0 & 0 & 0 \\
\hline p4 & HRV & 2.70 & 0 & 0 & 0 \\
\hline p5 & FluA & 7.53 & 6.00 & 6.52 & 5.48 \\
\hline p6 & neg & 0 & 0 & 0 & 0 \\
\hline p7 & neg & 0 & 0 & 0 & 0 \\
\hline p8 & COV & 0 & 0 & 3.99 & 3.29 \\
\hline p9 & Cov & 0 & 0 & 0 & 2.70 \\
\hline p10 & Cov & 2.70 & 0 & 0 & 0 \\
\hline p11 & neg & 0 & 0 & 0 & 0 \\
\hline p12 & cov & 3.40 & 2.70 & 4.84 & 0 \\
\hline p13 & COV & 0 & 2.70 & 0 & 4.71 \\
\hline p14 & Cov & 2.70 & 2.70 & 0 & 0 \\
\hline p15 & RSV & 5.34 & 0 & 3.26 & 0 \\
\hline
\end{tabular}

PIV = parainfluenza virus; HRV = human rhinovirus; FluA = influenza virus $A ; C O V=$ coronavirus; RSV = respiratory syncytial virus 
medRxiv preprint doi: https://doi.org/10.1101/2020.04.03.20051706; this version posted April 6, 2020. The copyright holder for this preprint (which was not certified by peer review) is the author/funder, who has granted medRxiv a license to display the preprint in perpetuity. It is made available under a CC-BY-ND 4.0 International license.

\section{Figure 1}

a) Flocked vs. foam swabs

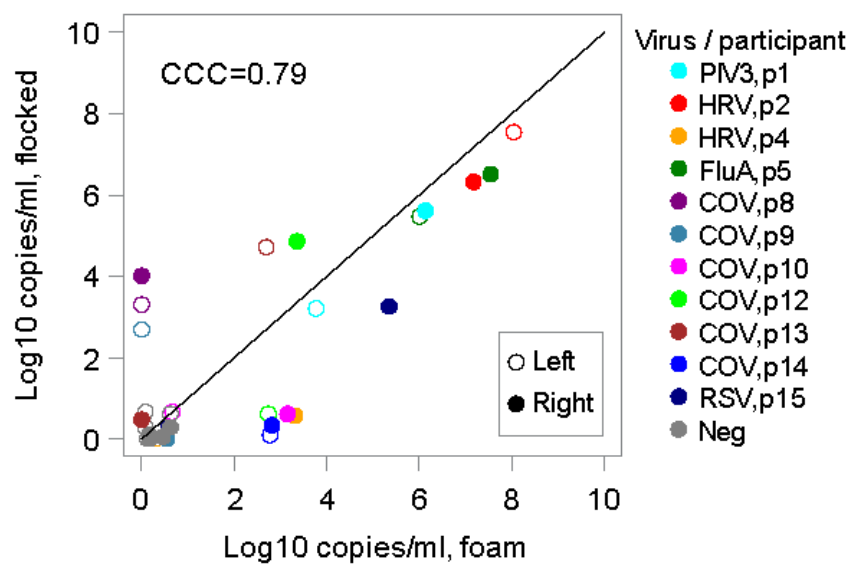

b) Right vs. left nostril

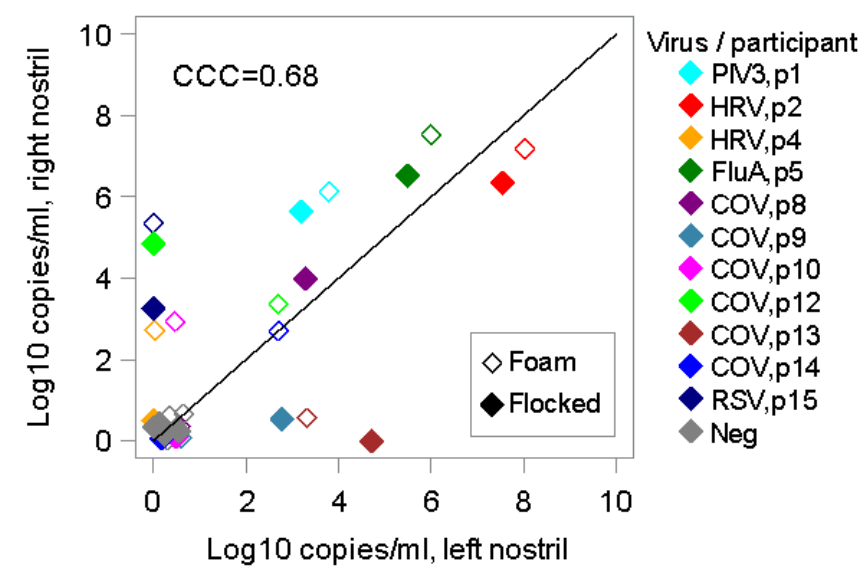

c) Sum vs. max of left and right nostrils

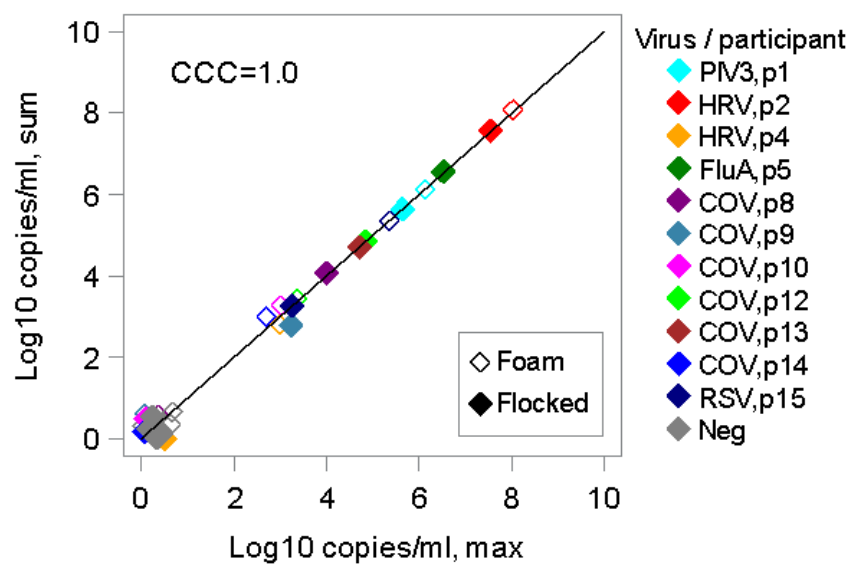


Figure 2

a)

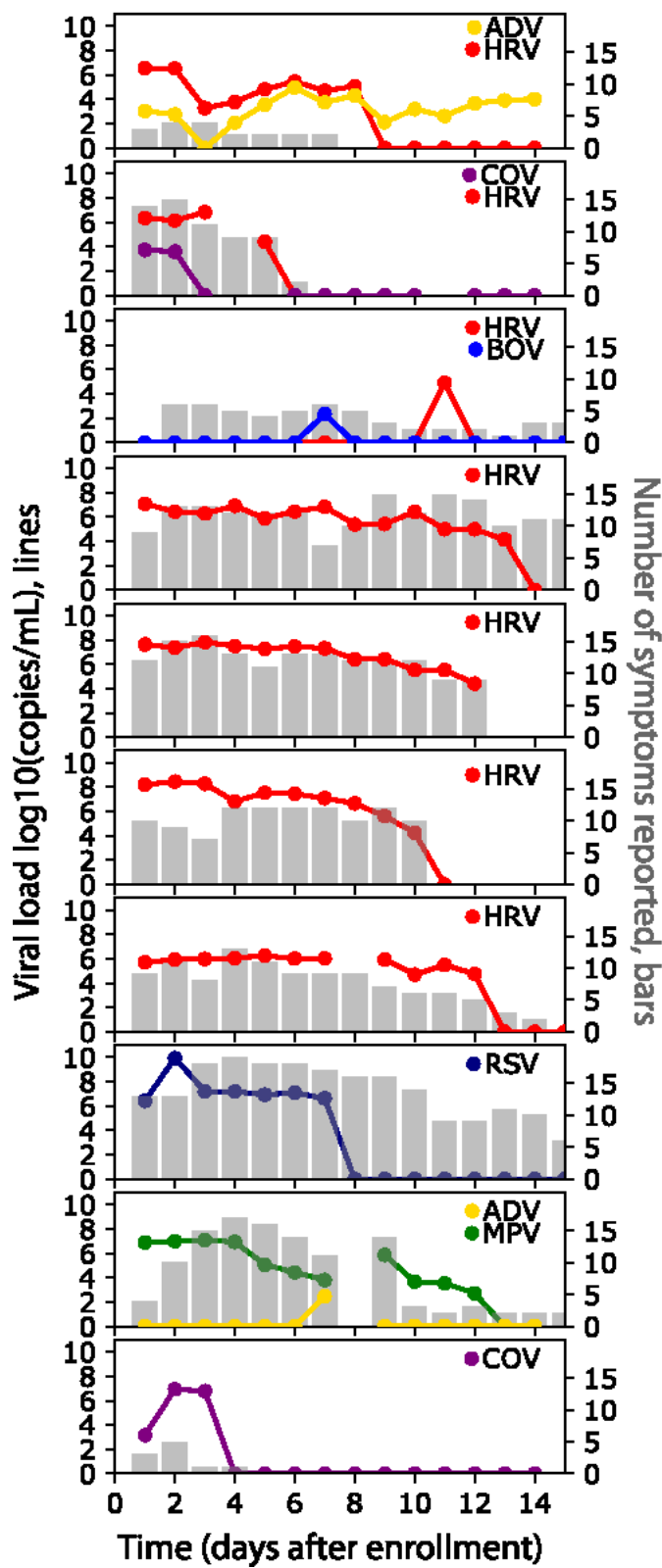

b)

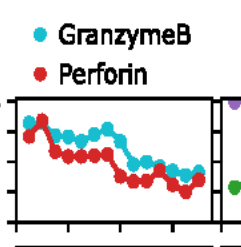

- IFN-g

- IP-10

- MP-1a

- $\mathbb{1}-6$

- II-12p70

- $\mathbb{L}-21$

p16
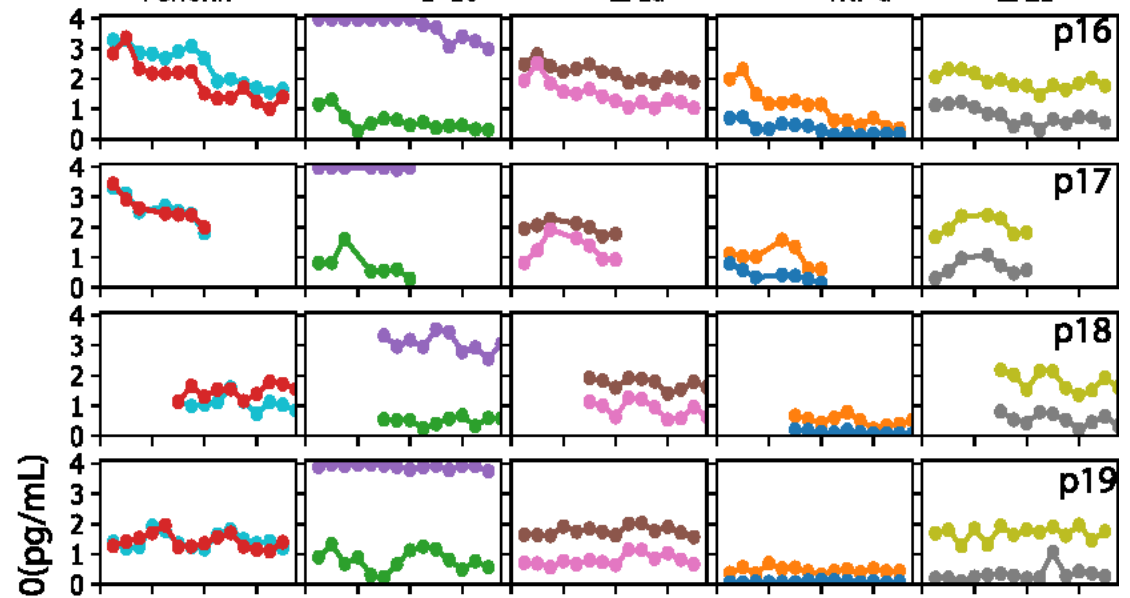

응
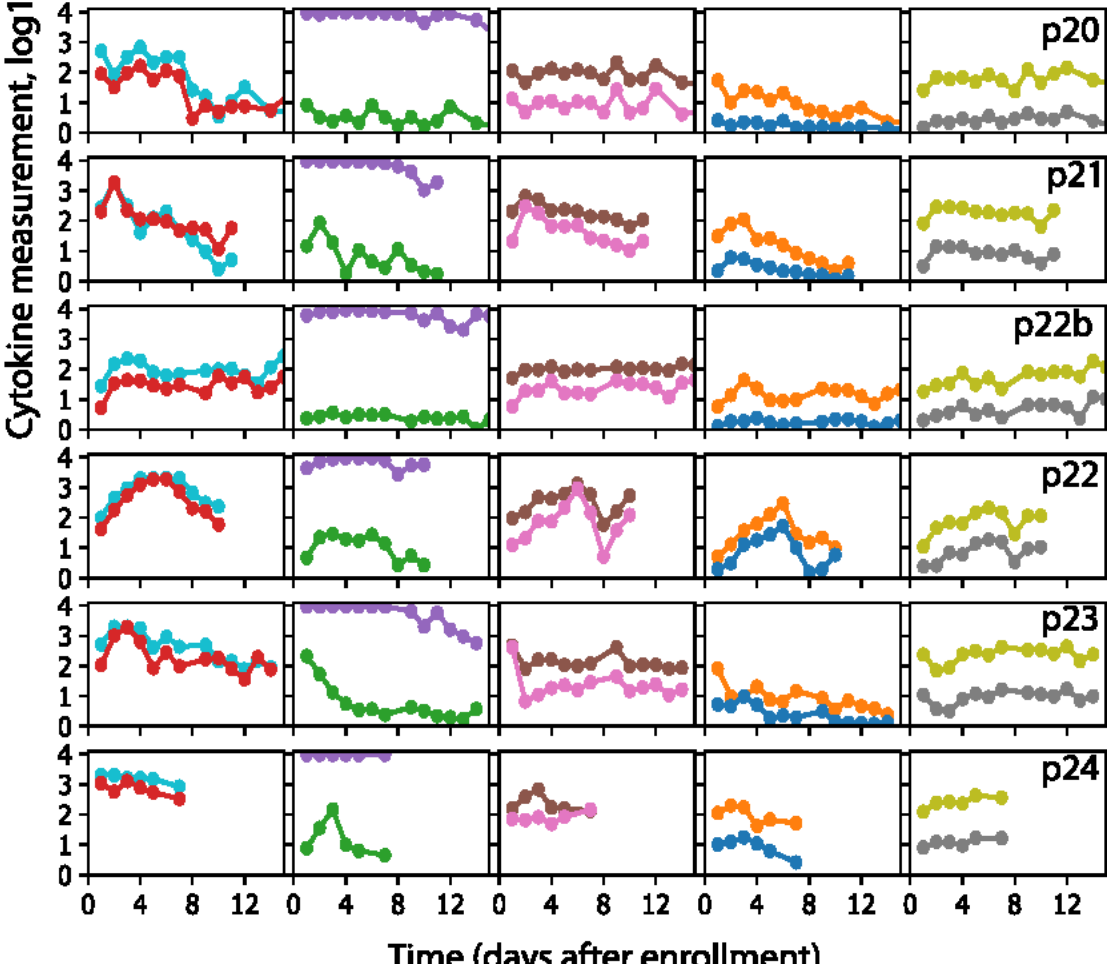

Time (days after enrollment) 
medRxiv preprint doi: https://doi.org/10.1101/2020.04.03.20051706; this version posted April 6, 2020. The copyright holder for this preprint (which was not certified by peer review) is the author/funder, who has granted medRxiv a license to display the preprint in perpetuity. It is made available under a CC-BY-ND 4.0 International license .

\section{Figure 3}

a)
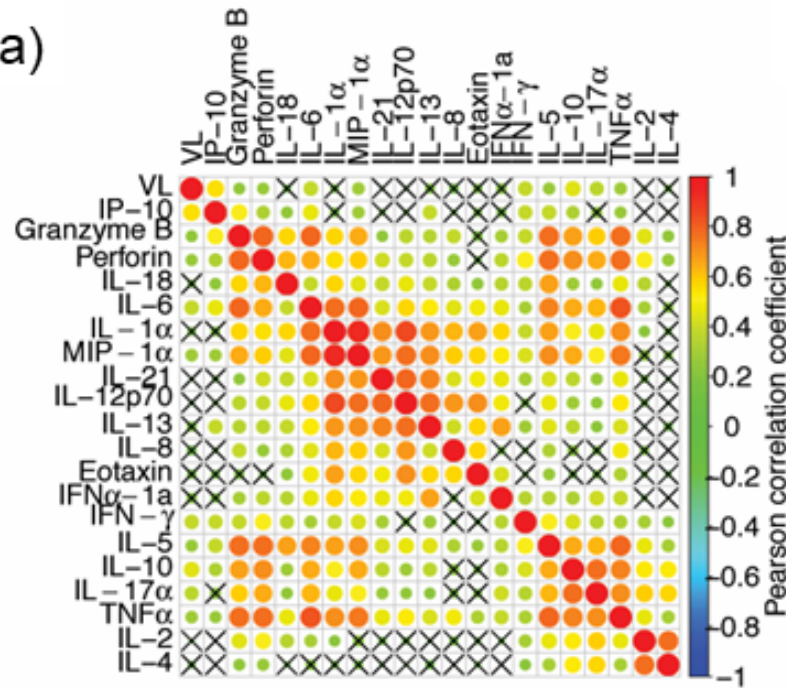

c)

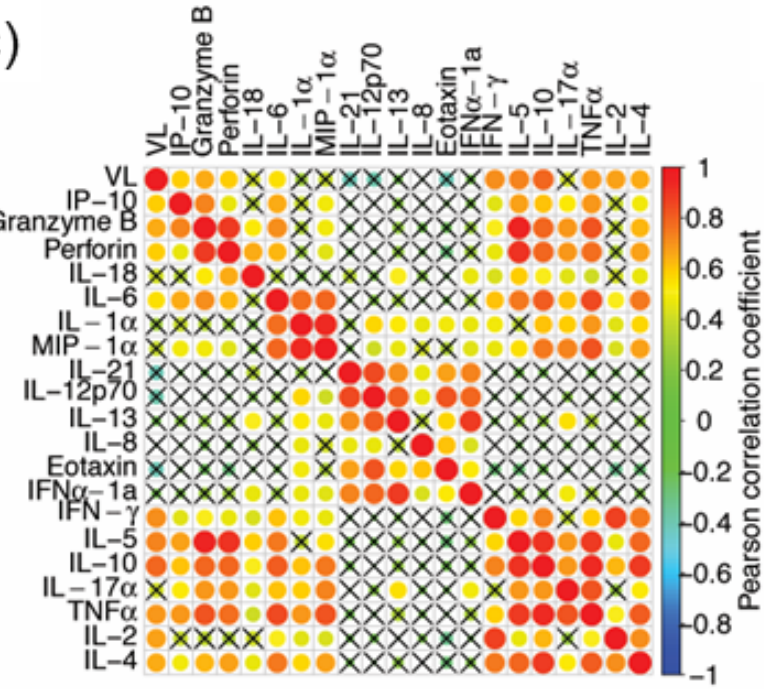

b)

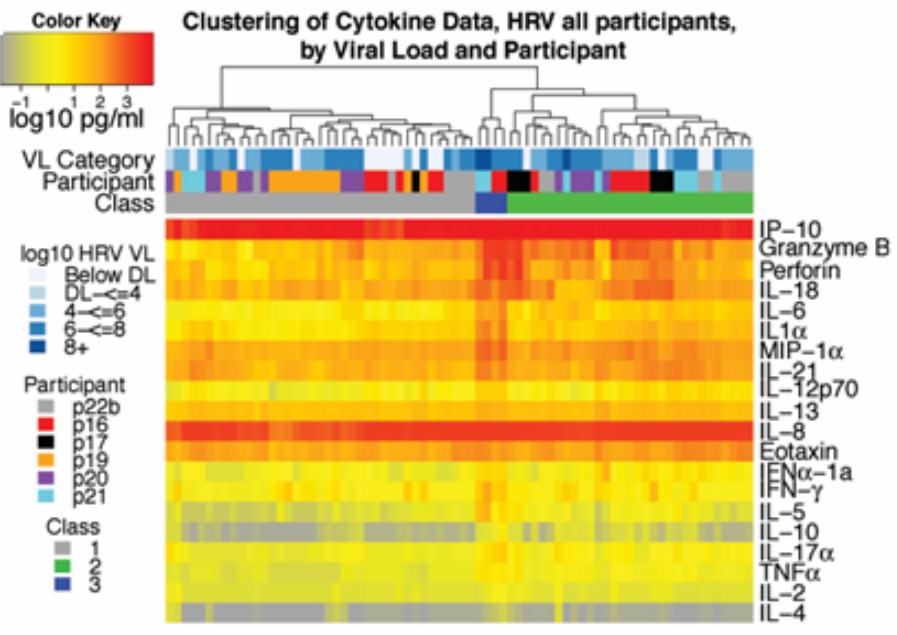

d)

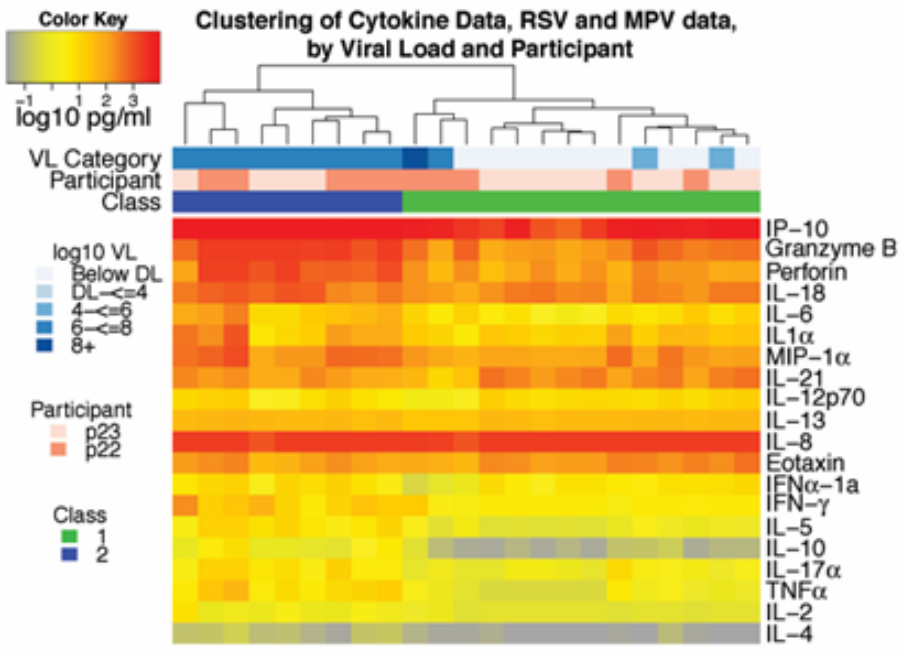




\section{Figure 4}

a)
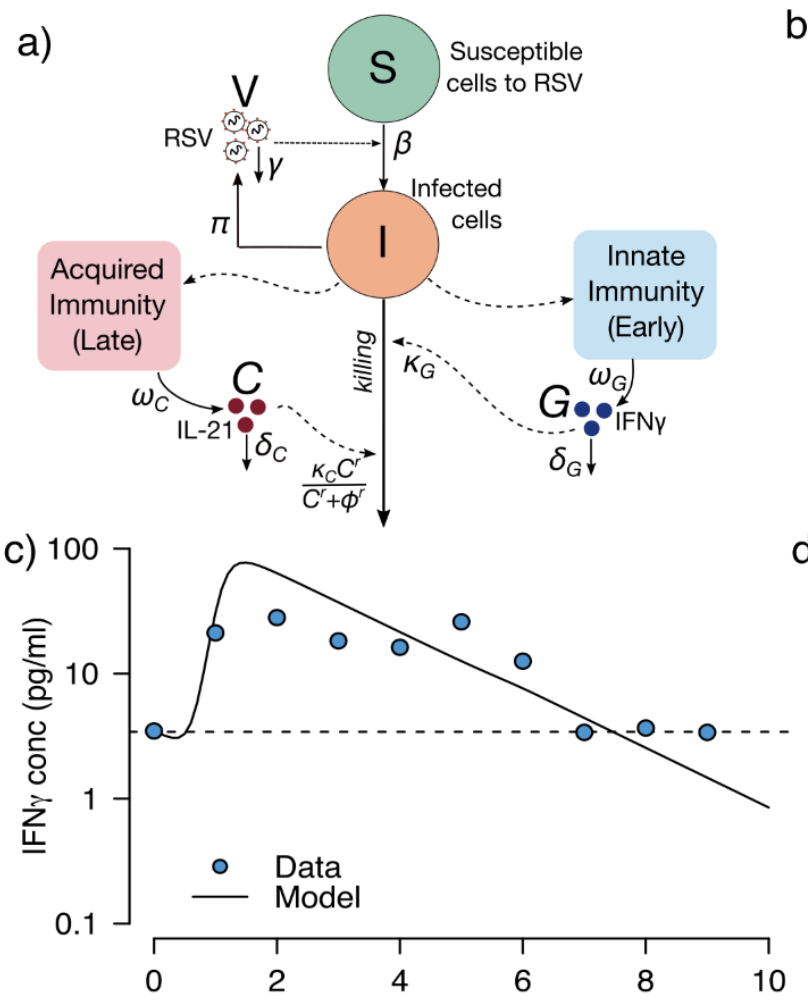

e)

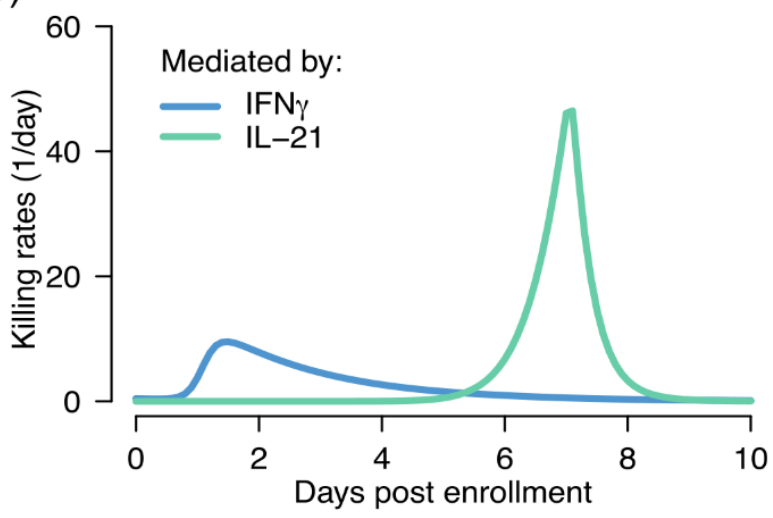

f) b)
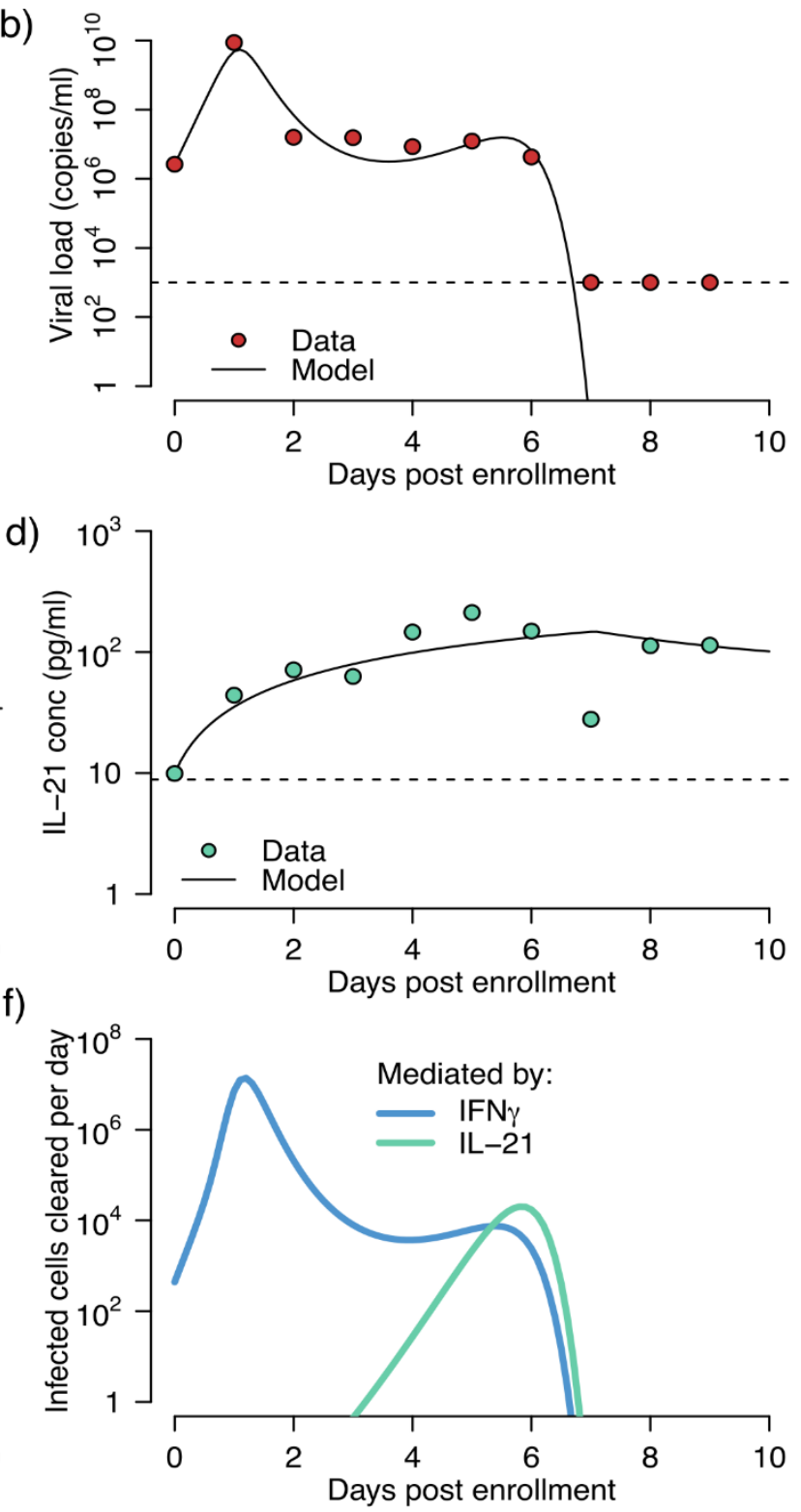
medRxiv preprint doi: https://doi.org/10.1101/2020.04.03.20051706; this version posted April 6, 2020. The copyright holder for this preprint (which was not certified by peer review) is the author/funder, who has granted medRxiv a license to display the preprint in perpetuity.

It is made available under a CC-BY-ND 4.0 International license .

\section{Supplemental Figure 1}

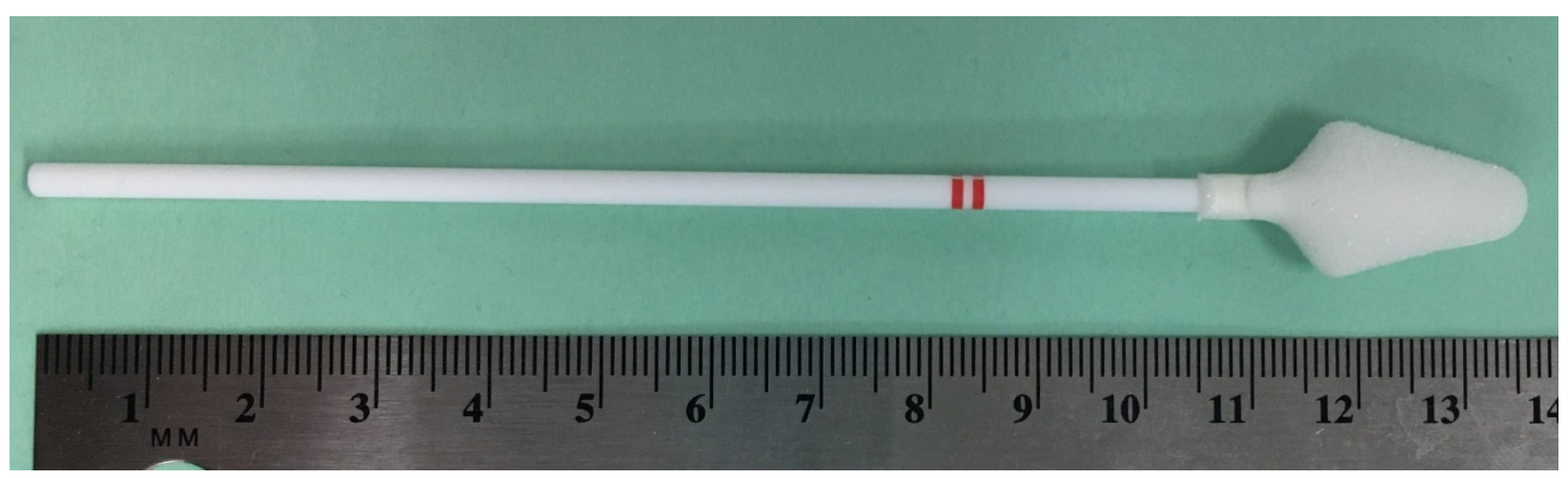




\section{Supplemental Figure 2}

a)

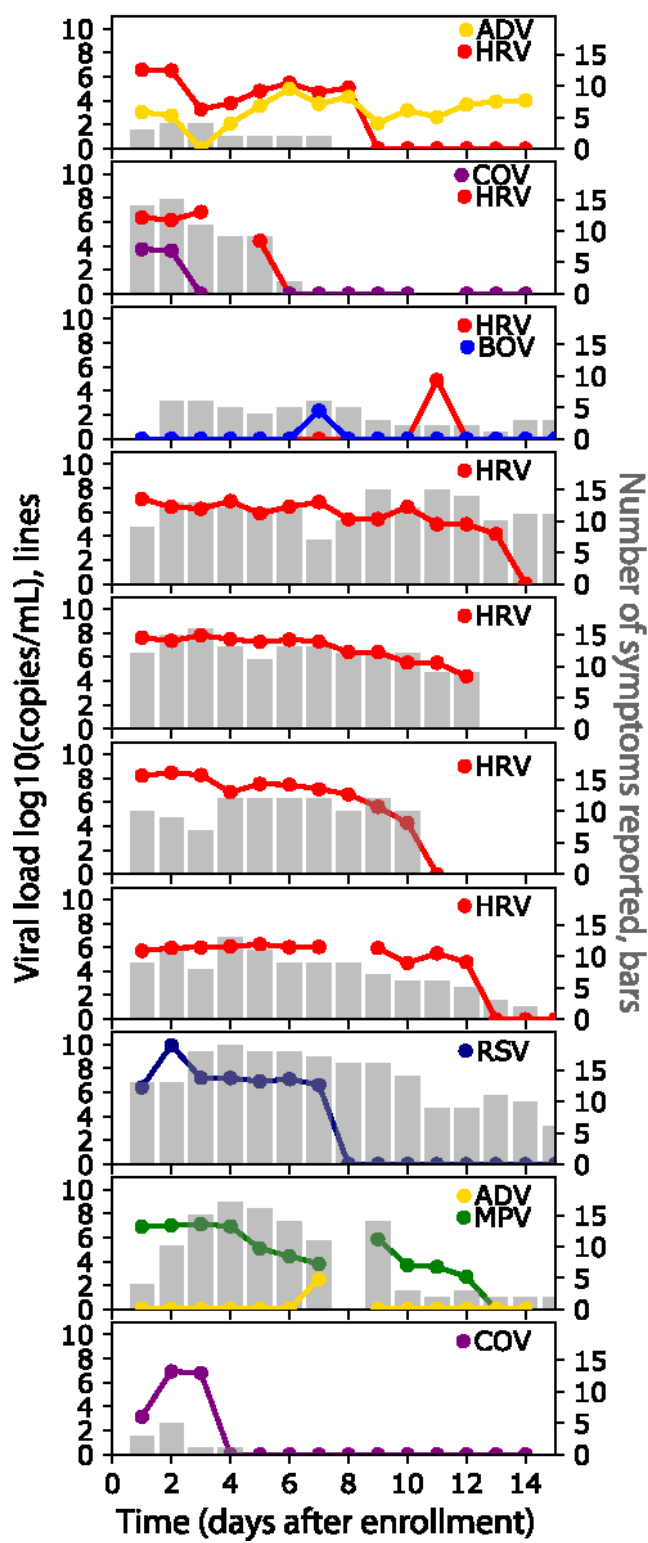

b)

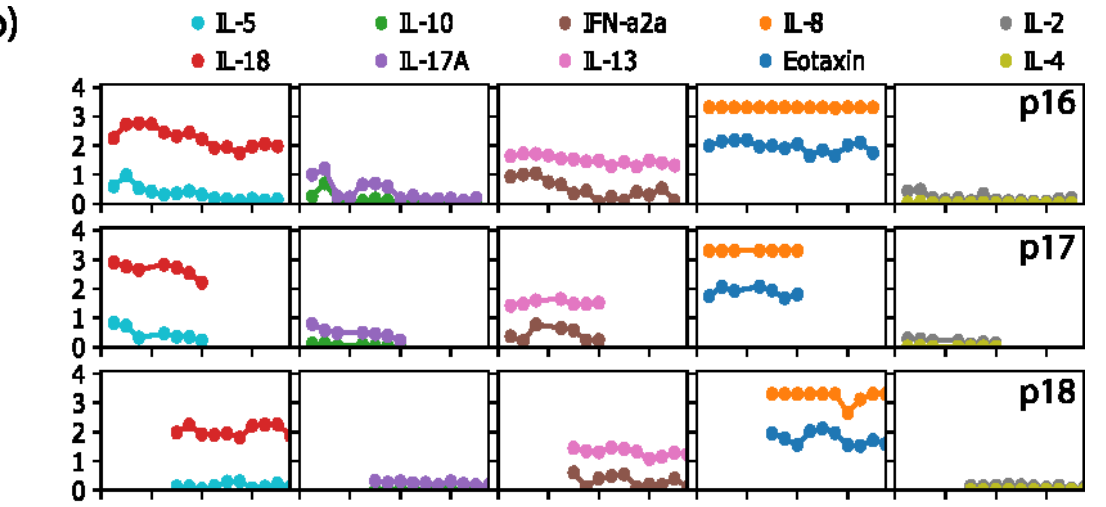

ह⿱\zh21
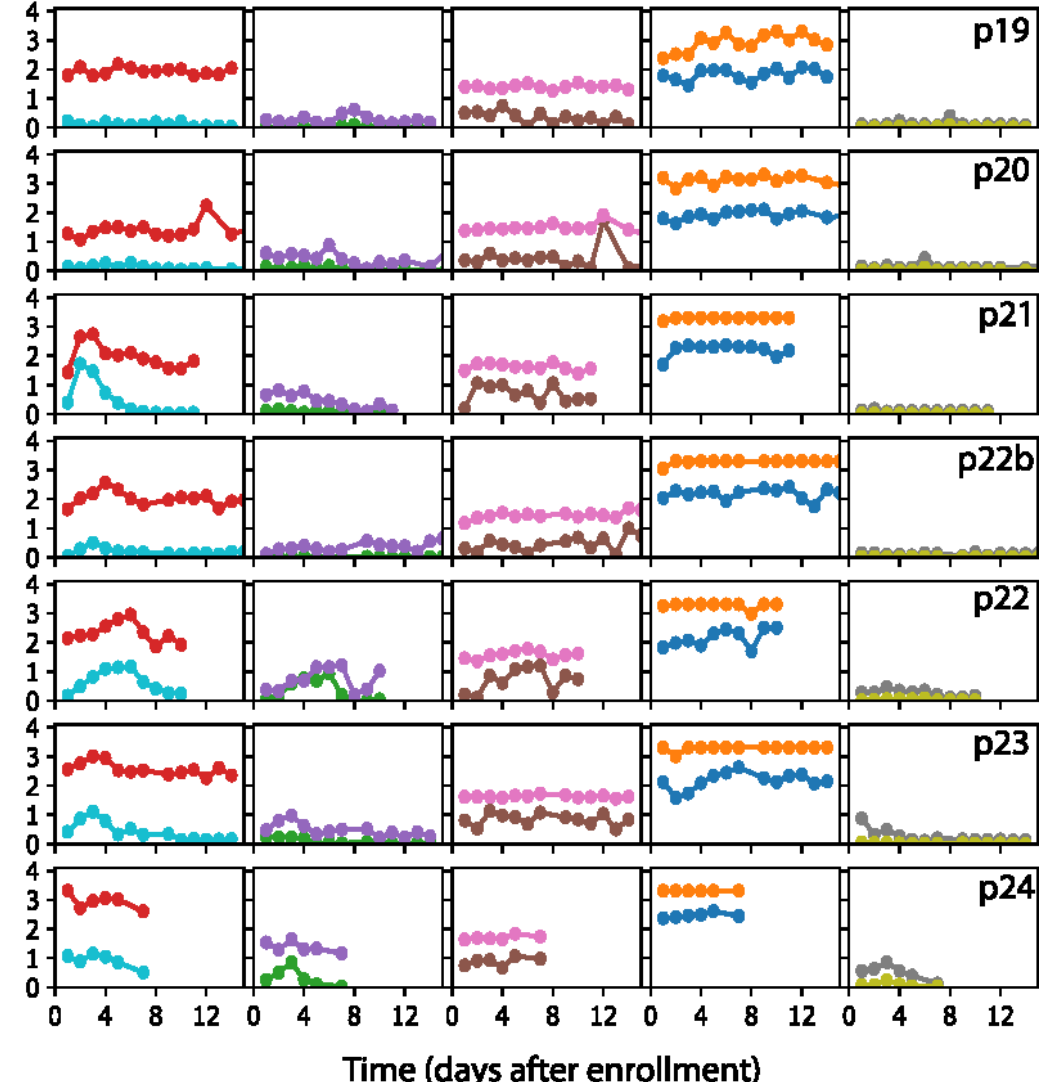
medRxiv preprint doi: https://doi.org/10.1101/2020.04.03.20051706; this version posted April 6, 2020. The copyright holder for this preprint (which was not certified by peer review) is the author/funder, who has granted medRxiv a license to display the preprint in perpetuity.

It is made available under a CC-BY-ND 4.0 International license.

\section{Supplemental Figure 3}

a)

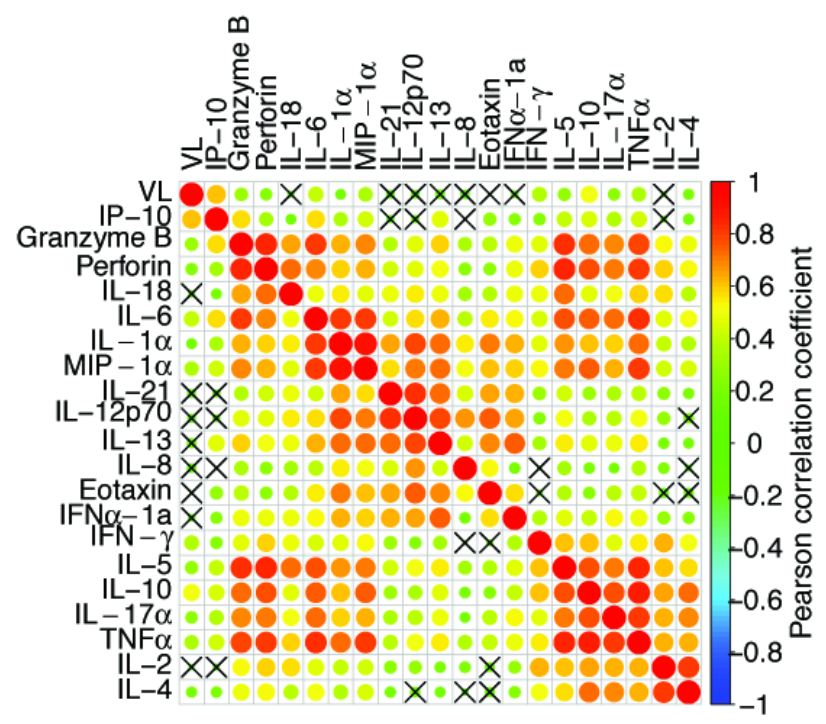

b)

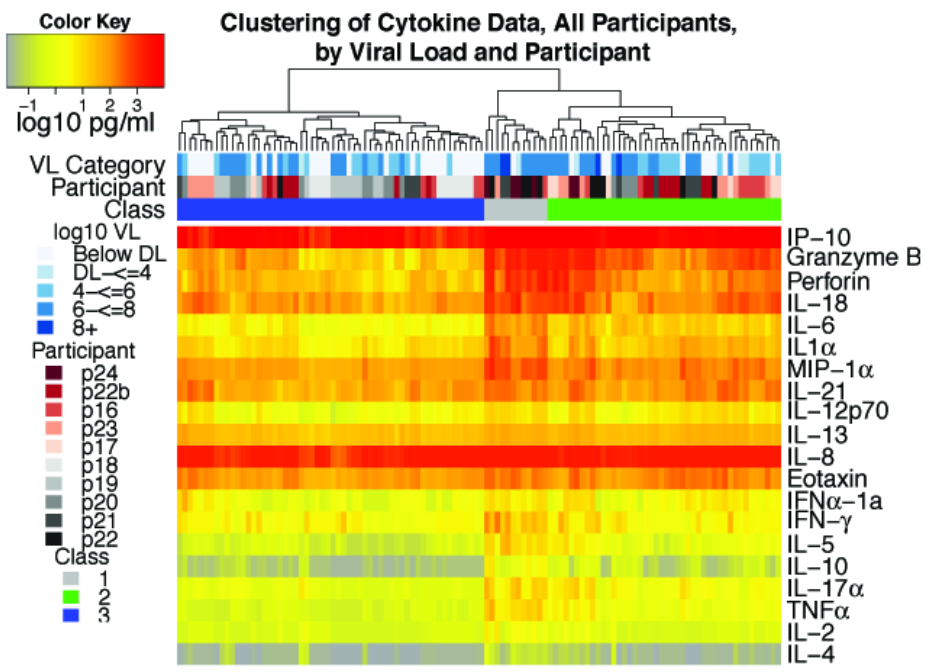




\section{Supplemental Figure 4}

a)

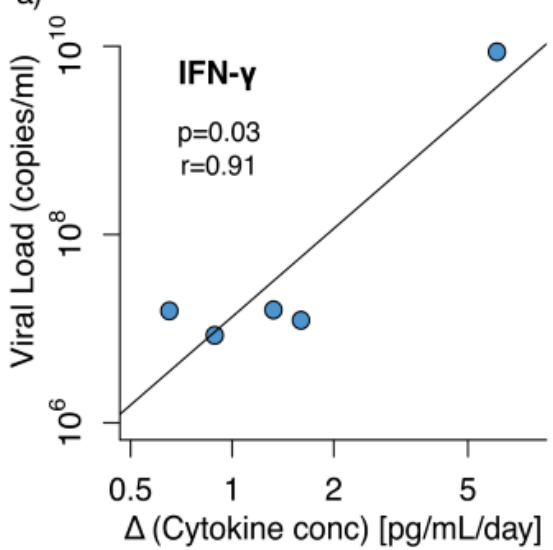

c)

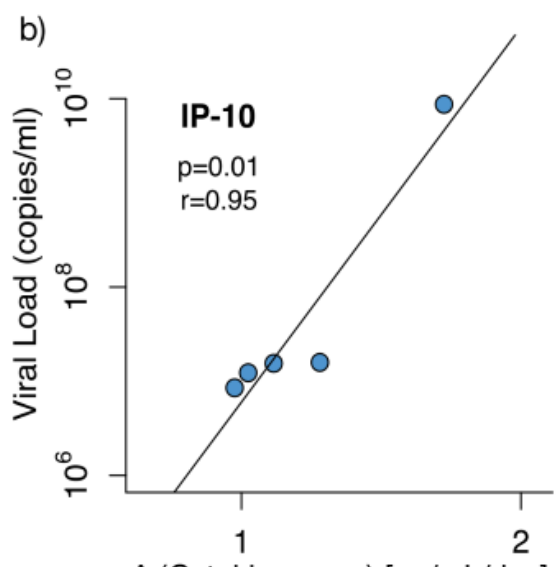

$\Delta$ (Cytokine conc) [pg/mL/day]
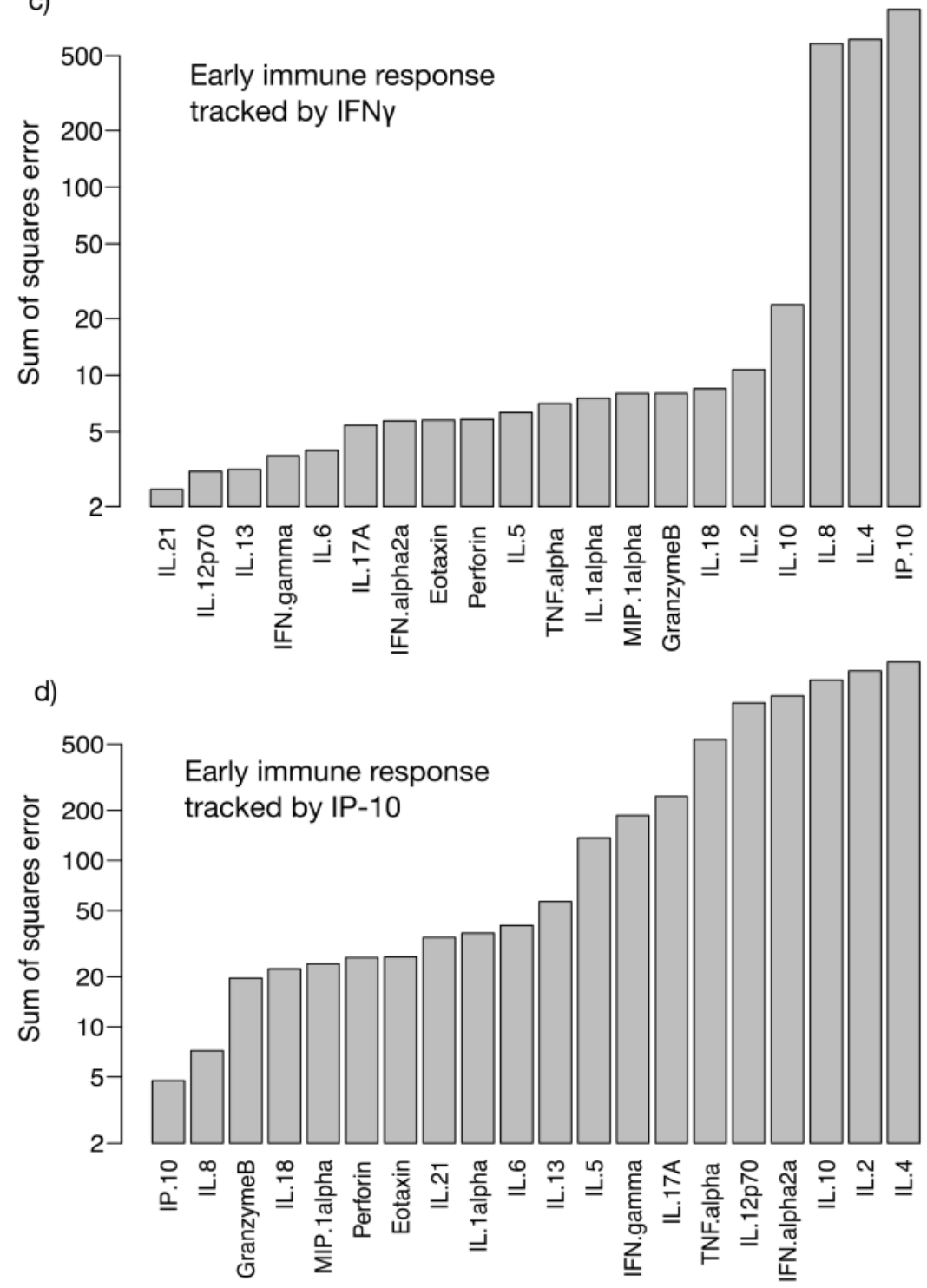


\section{Supplemental Figure 5}

a)

c)
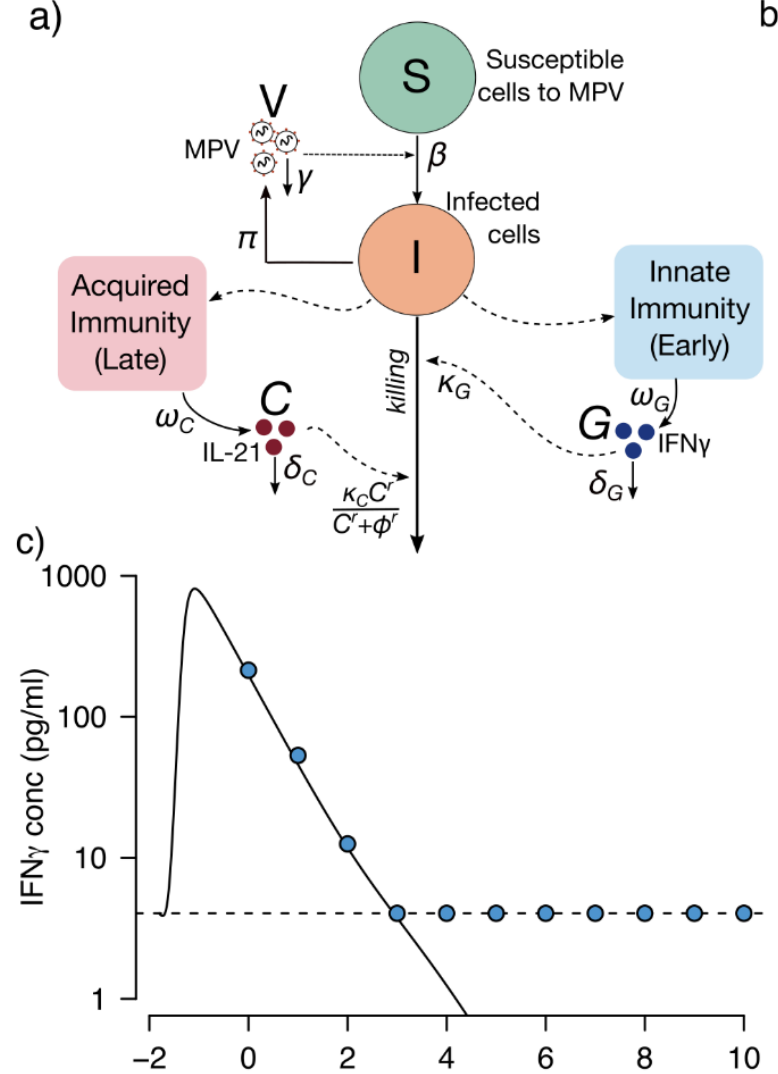

e)

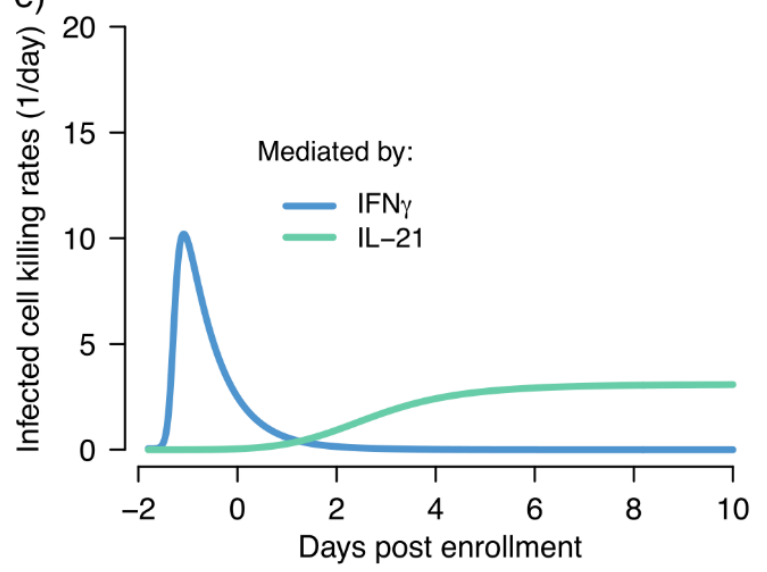

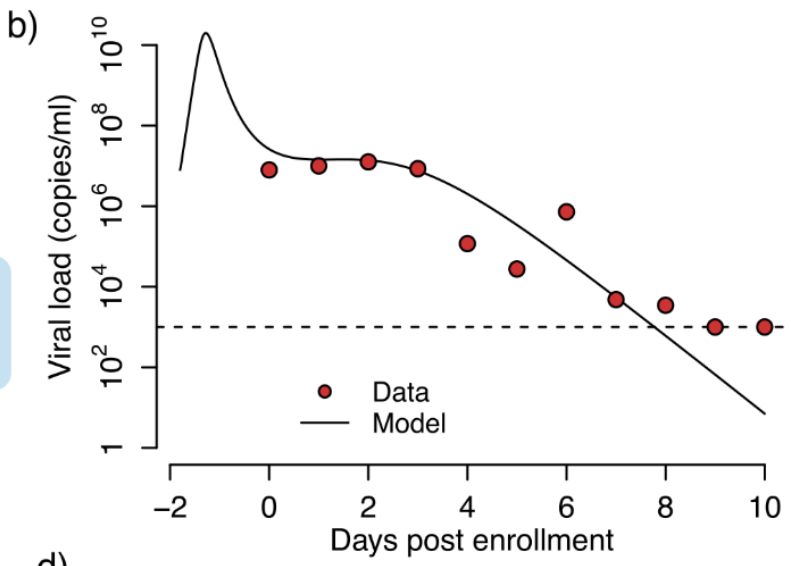

d)
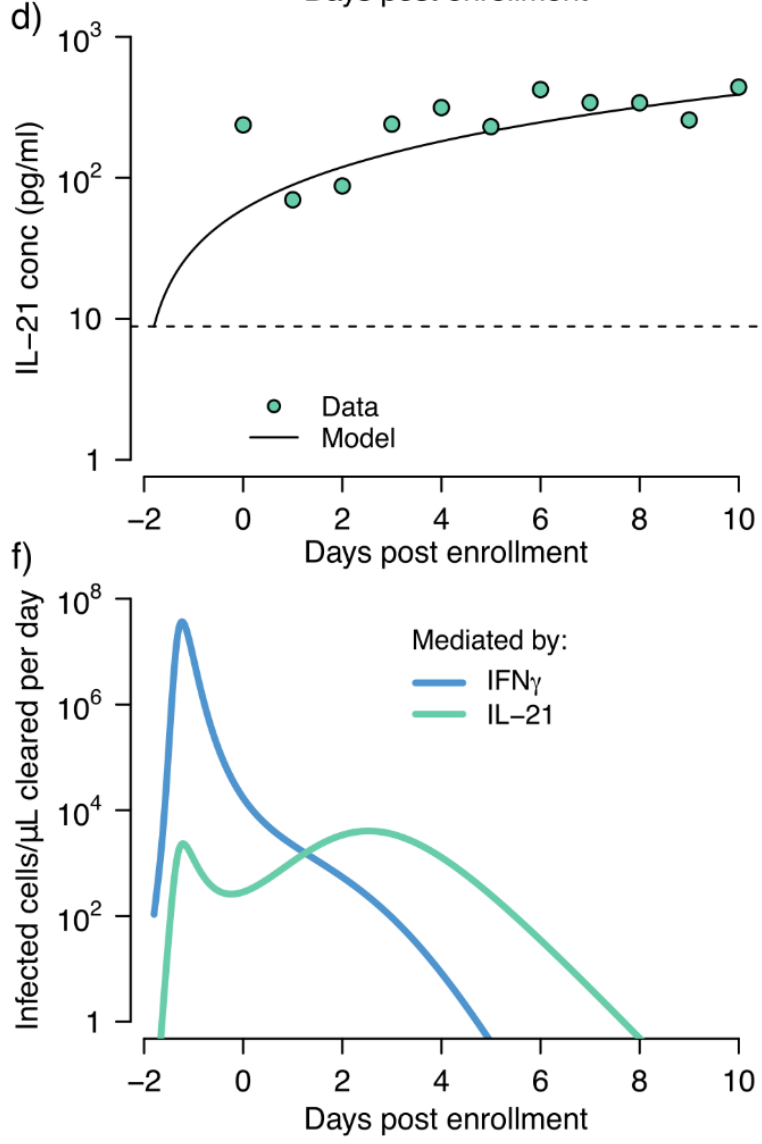
Supplemental Table 1: Symptom survey administered at enrollment (foam vs flocked swab comparison study) and daily (longitudinal sampling study).

\begin{tabular}{|c|c|}
\hline Symptom Category & Specific symptom \\
\hline \multirow{5}{*}{ Nose } & Runny nose \\
\hline & Congestion \\
\hline & Post-nasal drip \\
\hline & Sinus Pain \\
\hline & Sneezing \\
\hline Eyes & Watery/burning eyes \\
\hline Ears & Ear pain \\
\hline \multirow{2}{*}{ Throat } & Sore throat \\
\hline & Hoarseness \\
\hline \multirow{5}{*}{ Chest } & Cough \\
\hline & Phlegm production \\
\hline & Wheezing or chest tightness \\
\hline & Shortness of breath \\
\hline & Chest pain \\
\hline \multirow{4}{*}{ Gastrointestinal } & Diarrhea \\
\hline & Nausea \\
\hline & Stomach pain \\
\hline & Vomiting \\
\hline \multirow{5}{*}{ General } & Fatigue \\
\hline & Fever \\
\hline & Chills \\
\hline & Headache \\
\hline & Aching muscles \\
\hline Sleep Changes & Sleep Disruption \\
\hline \multirow[t]{2}{*}{ Sensory Changes } & Change in smell \\
\hline & Change in taste \\
\hline
\end{tabular}


Supplemental Table 2A: Foam versus foam swab concordance in left nostril.

\begin{tabular}{|l|l|c|c|c|}
\hline & \multicolumn{4}{|c|}{ Flocked Swab } \\
\hline \multirow{3}{*}{ Foam Swab } & & Positive & Negative & Total \\
\cline { 2 - 5 } & Positive & 4 & 2 & 6 \\
\cline { 2 - 5 } & Negative & 2 & 7 & 9 \\
\cline { 2 - 5 } & Total & 6 & 9 & 15 \\
\hline
\end{tabular}

Supplemental Table 2B: Foam versus foam swab concordance in right nostril.

\begin{tabular}{|l|l|c|c|c|}
\hline & \multicolumn{4}{|c|}{ Flocked Swab } \\
\hline \multirow{3}{*}{ Foam Swab } & & Positive & Negative & Total \\
\cline { 2 - 5 } & Positive & 5 & 3 & 8 \\
\cline { 2 - 5 } & Negative & 1 & 6 & 7 \\
\cline { 2 - 5 } & Total & 6 & 9 & 15 \\
\hline
\end{tabular}

Supplemental Table 2C: Foam versus foam swab concordance with results from left and right nostril combined.

\begin{tabular}{|l|l|c|c|c|}
\hline & \multicolumn{4}{|c|}{ Flocked Swab } \\
\hline \multirow{3}{*}{ Foam Swab } & & Positive & Negative & Total \\
\cline { 2 - 5 } & Positive & 9 & 5 & 14 \\
\cline { 2 - 5 } & Negative & 3 & 13 & 16 \\
\cline { 2 - 5 } & Total & 12 & 18 & 30 \\
\hline
\end{tabular}


medRxiv preprint doi: https://doi.org/10.1101/2020.04.03.20051706; this version posted April 6, 2020. The copyright holder for this preprint (which was not certified by peer review) is the author/funder, who has granted medRxiv a license to display the preprint in perpetuity. It is made available under a CC-BY-ND 4.0 International license .

\section{REFERENCES}

593 1. Dong, E., Du, H. \& Gardner, L. An interactive web-based dashboard to track COVID-19 $594 \quad$ in real time. Lancet Infect Dis (2020).

595 2. Onder, G., Rezza, G. \& Brusaferro, S. Case-Fatality Rate and Characteristics of Patients 596 Dying in Relation to COVID-19 in Italy. JAMA (2020).

597 3. Korean Society of Infectious, D., Korea Centers for Disease, C. \& Prevention. Analysis 598 on 54 Mortality Cases of Coronavirus Disease 2019 in the Republic of Korea from 599 January 19 to March 10, 2020. J Korean Med Sci 35, e132 (2020).

600 4. Patrick, G.T., et al. The global impact of COVID-19 and strategies for mitigation and $601 \quad$ suppression. (Imperial College London, 2020).

602 5. Gutierrez, P. Coronavirus mapped: which countries have the most cases and deaths? , 603 Vol. 2020.

604 6. Lipsitch, M., Swerdlow, D.L. \& Finelli, L. Defining the Epidemiology of Covid-19 - Studies $605 \quad$ Needed. N Engl J Med 382, 1194-1196 (2020).

606 7. Clark, T.W., et al. Viral load is strongly associated with length of stay in adults 607 hospitalised with viral acute respiratory illness. J Infect 73, 598-606 (2016).

608 8. Hijano, D.R., et al. Clinical correlation of influenza and respiratory syncytial virus load 609 measured by digital PCR. PLoS One 14, e0220908 (2019).

610 9. Fry, A.M., et al. Effects of oseltamivir treatment of index patients with influenza on 611 secondary household illness in an urban setting in Bangladesh: secondary analysis of a 612 randomised, placebo-controlled trial. Lancet Infect Dis 15, 654-662 (2015).

613 10. Liu, Y., et al. Viral dynamics in mild and severe cases of COVID-19. Lancet Infect Dis 614 (2020). 
615 11. Agyemang, E., et al. Herpes simplex virus shedding rate: Surrogate outcome for genital herpes recurrence frequency and lesion rates, and phase 2 clinical trials end point for

618 12. Duke, E.R., et al. Viral kinetic correlates of cytomegalovirus disease and death after

13. Green, M.L., et al. Cytomegalovirus viral load and mortality after haemopoietic stem cell transplantation in the era of pre-emptive therapy: a retrospective cohort study. Lancet

14. Natori, Y., et al. Use of viral load as a surrogate marker in clinical studies of cytomegalovirus in solid organ transplantation: A systematic review and meta-analysis. Clin Infect Dis 66, 617-631 (2018).

15. Murray, J.S., Elashoff, M.R., lacono-Connors, L.C., Cvetkovich, T.A. \& Struble, K.A. The use of plasma HIV RNA as a study endpoint in efficacy trials of antiretroviral drugs. AIDS

16. Feld, J.J., et al. Sofosbuvir and velpatasvir for HCV genotype 1, 2, 4, 5, and 6 infection. N Engl J Med 373, 2599-2607 (2015).

631 17. Feld, J.J., Wong, D.K. \& Heathcote, E.J. Endpoints of therapy in chronic hepatitis B. Hepatology 49, S96-S102 (2009).

633 18. Topham, D.J. \& Reilly, E.C. Tissue-Resident Memory CD8(+) T Cells: From Phenotype to Function. Front Immunol 9, 515 (2018).

635 19. Cheng, M. \& Hu, S. Lung-resident gammadelta T cells and their roles in lung diseases. Immunology 151, 375-384 (2017).

637 20. Kandasamy, M., Furlong, K., Perez, J.T., Manicassamy, S. \& Manicassamy, B.

638 Suppression of Cytotoxic T Cell Functions and Decreased Levels of Tissue Resident 639 Memory T cell During H5N1 infection. J Virol (2020). 
medRxiv preprint doi: https://doi.org/10.1101/2020.04.03.20051706; this version posted April 6, 2020. The copyright holder for this preprint (which was not certified by peer review) is the author/funder, who has granted medRxiv a license to display the preprint in perpetuity. It is made available under a CC-BY-ND 4.0 International license .

640 21. Smith, A.P., Moquin, D.J., Bernhauerova, V. \& Smith, A.M. Influenza Virus Infection Model With Density Dependence Supports Biphasic Viral Decay. Front Microbio/ 9, 1554

643 22. Roychoudhury, P., et al. Tissue-resident T cell derived cytokines eliminate herpes 644 simplex virus-2 infected cells. J Clin Invest (2020).

645 23. United States Food and Drug Administration. FAQs on Diagnostic Testing for SARS$646 \quad$ CoV-2. Vol. 2020.

647 24. Campbell, A.P., et al. Self-collection of foam nasal swabs for respiratory virus detection by PCR among immunocompetent subjects and hematopoietic cell transplant recipients.

25. Preiksaitis, C.M., et al. A patient self-collection method for longitudinal monitoring of respiratory virus infection in solid organ transplant recipients. J Clin Virol 62, 98-102 (2015).

26. Fisher, C.E., Boeckh, M., Jerome, K.R., Englund, J. \& Kuypers, J. Evaluating addition of

27. van Doremalen, N., et al. Aerosol and Surface Stability of SARS-CoV-2 as Compared with SARS-CoV-1. N Engl J Med (2020).

28. Schiffer, J.T., et al. Mucosal host immune response predicts the severity and duration of

29. Antunes, K.H., et al. Respiratory syncytial virus reduces STAT3 phosphorylation in human memory CD8 T cells stimulated with IL-21. Sci Rep 9, 17766 (2019).

663 30. Dodd, J.S., Clark, D., Muir, R., Korpis, C. \& Openshaw, P.J. Endogenous IL-21 regulates pathogenic mucosal CD4 T-cell responses during enhanced RSV disease in mice. 
medRxiv preprint doi: https://doi.org/10.1101/2020.04.03.20051706; this version posted April 6, 2020. The copyright holder for this preprint (which was not certified by peer review) is the author/funder, who has granted medRxiv a license to display the preprint in perpetuity. It is made available under a CC-BY-ND 4.0 International license .

666 31. Gassen, R.B., et al. RSV Downregulates IL-21/IL-21R on TFH cells via PD-L1 induction 667 in APCS impairing protective humoral responses. 203133 (2017).

668 32. Kuypers, J., et al. Comparison of real-time PCR assays with fluorescent-antibody assays 669 for diagnosis of respiratory virus infections in children. J Clin Microbiol 44, 2382-2388 $670 \quad$ (2006).

671 33. Lin, L.I. A concordance correlation coefficient to evaluate reproducibility. Biometrics 45, $672 \quad$ 255-268 (1989).

673 34. Hopkins, B. \& Skellam, J.G. A New Method for determining the Type of Distribution of $674 \quad$ Plant Individuals. Ann Bot, 213-227 (1954).

675 35. Banerjee, A. \& Dave, R.N. Validating clusters using the Hopkins statistic. in 2004 IEEE International Conference on Fuzzy Systems (IEEE Cat. No.04CH37542), , Vol. 1 149-153 (Budapest, Hungary, 2004).

678 36. R Core Team. R: A language and environment for statistical computing. (R Foundation 679 for Statistical Computing, Vienna, Austria, 2018). 